\section{4. 酸化防止剂の作用機構}

\section{4.a 酸化防止剂の作用する段階}

炭化水菜の自働酸化は上述の上らに種々の原因でラシ カルが生じて，これが酸秦と反応してhpoとなり，つき にこれが炭化水素から水壆を暃って炭化水素のラシカル ができて進行する連鎖反応であって，この連鎖は複雑な termination によって切断されるすのである.

この連鎖をいずれかの反応段階で切断すれば，自働酸 化反応は進行しなくなる.これが酸化防止剤の作用の本

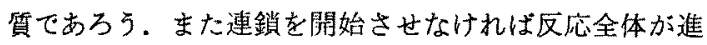
行しなくなるが，そのためには初めにラジカル生成の要 园となる光などの影響をなくすことも考光られる。

酸薪に着目して考学れば，第一段階は気相の酸素が被 酸化体表面に拡散して行く過程であるが，これはゴムの ような固体では表面をたとえば micro crystalline wax などで被膜して防止することができる。これは運鎖反心 には無関係な純物理的な問題であるが，同様な例は尿素 または $\alpha, \beta$, dextrin deoxycholic acid との附加物ま たは抱合によるりノレイン酸などの酸化防止がある113)。

Water $^{1-g}$ は inhibitor てしまうもので，hpo分子自身をつぶすすのではない している.

また3.fで述べたよ5にアルコールやフェノールは induction period を延長するが，反応生成物にほとん ど影響がない.

K.I. Ivanon 114〉 らの実験によると，よく精製した絋 油を鉄, 銅などの触媒の存在て $120^{\circ} \mathrm{C} て ゙$ 酸素を通過させ あらかじめ酸化したものとこのような好理をしなかっ たものに酸化防止剂を0.01モル\%添加すると，醉化防止 に効果を示す添加凨とそうでないものとがある。

$p$-hydroxydiphenylamine, phenyl- $\beta$-naphthylamine, diethyl-p-phenylenediamine, $4,4^{\prime}$, diamino diphenyl sulfide は酸热を通じてあらかじめ酸化する 以前に添加するといずれるよい酸化防止剂であるが，予 備酸化などによって一部酸化が起った後では前二者では

\footnotetext{
*(その1) は本誌第32巻第9号に揭㦲
}

** 川口.化学工業株式会社
酸化はそのまま進行する，しかるに後二者ではそれ以上 の酸化は阻止される、すなわち前二者は初期の活性なも のを抑制する・それは連鎖を出発させる initiation の部 分である、しかし過酸化物の存在する段階に忧無力であ る、すなわち propagation の段階では無力であると思 われる.この上うに酸化防止凧の作用機構は招のおの異 なるむのと思われる。

松本によれば炭化水票の液相加圧酸化はその構造と密 接な関係があり，酸化の進行に伴なって過酸化物の最高 䈏積期お゙よびカルボニル蓄積期が現われる. ethyl ben zene を用いこれに安息香酸添加すると，過酸化物の 蓄積が促進され，またカービノール，およびアセトフェ ノールは過酸化物の蓄積期の出現を遅らせる ${ }^{115)}$.

過酸化物の濃度が増加するとフェノールの酸化防止作 用は低下するが，この場合效果のあるのは比較的簡单な フェノール類で， $\alpha$ ナフトールなどである.

金属の存在は酸化を促進するが，アルコールや水はこ れを抑制する. それは次式のようにROO-がラジカルに なる段階を防害するためである。

$$
\begin{aligned}
& \mathrm{ROO}^{-}+\mathrm{R}^{\prime} \mathrm{OH} \longrightarrow \mathrm{ROOH}+\mathrm{R}^{\prime} \mathrm{O}^{-} \\
& \mathrm{ROO}^{-}+\mathrm{M}^{++} \longrightarrow \mathrm{ROO}^{\prime}+\mathrm{M}^{+}
\end{aligned}
$$

Emerson は水による抑制は極性のある水によって金 属触媒が不活性化されるためだといっている，金属の存 在しない場合におけるアルコールの作用をつぎに示す 94a).

$$
\mathrm{ROH}+\cdot \mathrm{OH} \longrightarrow \mathrm{RO} \cdot+\mathrm{H}_{2} \mathrm{O}
$$

これはRO・より・OHの方がすっと速かに反心するた めである.

ゴムのベンゼン溶液におけける酸素の吸収によって生じ る $\mathrm{C}=\mathrm{O}$ の㤝度を赤外吸収スペクトルで測定し，酸化時 間とその生成量の間に第 2 図のよ5な二種の傾问を示す 酸化防止㓮のあることを Kellb らが見出しだ1。第2 図中 I retarder でＩIは inhibitor であるとし た，彼らは酸化防止剤はAH型で炭化水秦ラシカルとの 間につきの反応がおこりこの平衡が右に多く寄っている

$\mathrm{AH}+\mathrm{R} \cdot \longrightarrow \mathrm{A} \cdot+\mathrm{RH}$

ほど induction period が長く，またA・が不活性なら inhibitor となり，A・が活性なら retarder型になると考 


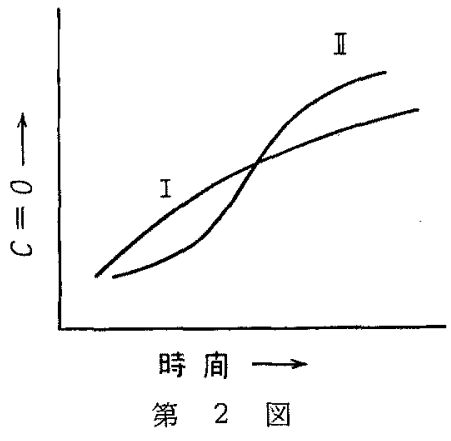

えた、安たつぎの反応が強く捛こればよいinhibitorで あると述へている。

Termination の速度が堌せば，反応速度俚減少する

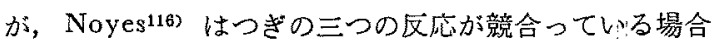
scavengering agant $\mathrm{S}$ の濃度とtermination の速度の 関係を考察した. terminationにつぎの種類があるとし た.すな施

$$
\begin{array}{ll}
\mathrm{R}_{0} \cdot+\mathrm{R}_{0} \cdot \longrightarrow \mathrm{R}_{2} & \text { recombination } \\
\mathrm{R}_{0} \cdot+\mathrm{S} \longrightarrow \mathrm{P} & \text { scavenger } \\
\mathrm{R}_{0} \cdot+\mathrm{R} \longrightarrow \longrightarrow \mathrm{R}_{2}^{\prime} & \text { other radical combination }
\end{array}
$$

それによれば，第 3 図のようにS の浱度がますと scavenger は增大するが遂に一定值に達するものであ る。すなわちこの上うな酸化防止剂には濃度を增加して も，も早や効果の增大しなくなる点がある。

G.W. Kennerly，W. L. Patterson ${ }^{17)}$ は石油系に対す

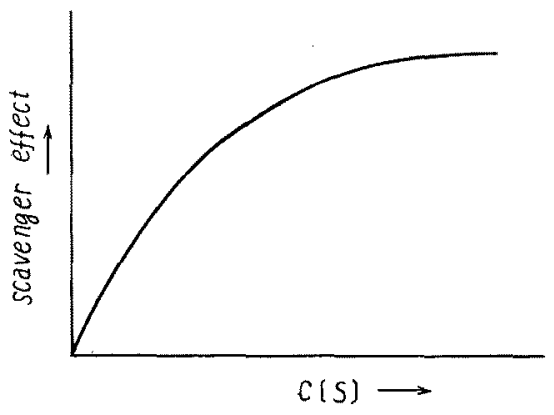

第 3 区

る醉化防止剤:ついて咞究してつぎの三つの分類老考党 た。

(1) Metal deactivator

(2) Inhibitor

(3) Peroxide decomposer

（1）について金属に対する種々のキレート化合物があ る.鉄，銅などの金属のある場合の油の酸化についての
研究をLosen が行なっている.1182.

（2）は芳香族アミンおよひフェノール類である.

（3）各種のものがあるが，含硫黄化合物が多い.

前章に述べた酸化機棈によれば，もっとるよい酸化防 止剂の可能性の一つはラシカルに水素をあたえやすいる のである。しかし水素との結合のあまりに弱いるの淡次 式で示されるように直淁酸紫によって政摮されるのでむ $\mathrm{AH}+\mathrm{O}_{2} \longrightarrow \mathrm{A}=+\mathrm{HOO}$.

しろ initiator となるから，酸化防止剂として働くため には水素の結合は丁車適当でなければならない：この考 方方は酸化還元電位が適当なりのか酸化防止剂になると いう絬果と一致している.

Bolland 怙よび Ten Have119) の実駼はオレフィン のような易酸化性物領を用いているので hpo の濃度が 大であり，加えられた酸化防止剂の瀇度は低いから， initiation は大部分が hpo の分解によるるのであり， また酸素の吸收速度は propagation の速度すなわ占 反心（A-3）の速度を直接測定したものである。 — (Bolland 50実験に用いた $\mathrm{BzO}_{2}$ は induced decomposition があり，また供試された linoleate のよ うな diene 類は精製が困難であることから， Bickel， Koogman は別に 2,2,3,3 tetraphenylbutane を分解 させて生じたラジカルを酸化して alkyl peroxy radical をつくり，また被酸化体である炭化水素としては 9,10 dihydroanthracene を用いて実䮖している。この置換 ブタンの分解速度は $60.06^{\circ} \mathrm{C}$ に㧊いて $k_{D}=2.065 \times$ $10^{-4}\left(\mathrm{sec}^{-1}\right)$ の筫分子反応である。ただ Bickel らは このように被酸化体の酸化によって生じる以外の異種の hpo を用いていることについては，このhpoはdihydroanthracene $の \mathrm{hpo}$ と同様の反応をするすので; 異 種のものを用いることによって機满が変ることはないと のべている，一方異種の hpoを加充ると酸化の様子が変 化することについては Hocks らの研究があって，これ についてはすでにのベたところである.)一一

しかるに，石油のような飽和炭化水素を主とするもの ではpo の濃变は低くしたがって hpo の分解によらな い他の原因による initiation が大きな比重を占めてい る.また易酸化性でないから反応遭鎖ば般に㛒かくな る.とくに酸化防止版のある場合はこれ各 hydroperoxy radical を攻揧するので，反応連鎖往ますます短か くなる、したがって全反応速度は initiationの速度によ って大いに支配される。

上述のように，三種の分類を基磷つける特性反応とし て Kennerly らはcumene の hpoの溶液に添加した場 
合の举動をあげている.

cumene $の$ hpo の分解速度かi排制され，生成物が フェノールを含まないものは inhibitor であるとされて いる，また分解が促進されるすのは peroxide decomposer であるとされる，これに類似しているが䁷移金 属や，ある種のアミンは過酸化物の分解を促進するが酸 化防止作用はない：これらはまた分解生成物としてフ ェノールをあたえない。むしろ酸化の正触媒であ 3.

Na-butadiene ゴムの酸化の Kuzuminski120) ら の研究によると，酸秦吸収には酸化中間体の褔積期 と自㗢酸化期の二期がある，第二級アミン系の酸化 防止剂は初期の酸化反応字抑制寸る，そうして生成 物は酸化防止剤が存在する場合はアルデヒドであ る、無添加の場合は架橋がおこるが，添加してある と分子の切断がおこる。また酸化防止剂が過剩なとき は，その中間酸化生成物であるラシカルが開始肪とな り， chain transfer を抗こして酸化は却って捉進され る、また第二級アミン類の酸化防止の効果は，NH団の Hの易動性に支配される．芳香族の核が多く共斬結合の 効果の大なるものは酸化防止効果が大である。

反応の出発点となるラジルの生成を防止するものむ 酸化防止冎として作用する訳でする。 initiation には 熱分解によってラジカルの生ずるすのもあるが，光化学 的に炭化水素加分解されることすある，そこて光を吸収 し無害なエ六ルギーの形にする添加剂が考えられてい る.

紫外線はとくにエネルギーが高いのでこの害を防止す るために加えられる添加剂が U、V， absorber であ る、通常の酸化防止剤はこの光による部分を抑制できな い212.

サルチル酸フェニルはアセチルセルローズの光安定剤 として以前から知られていたものであるが，その他にも 広く用いられている(22)，resorcinol monobenzoate は 酸化防止削としては有効であるが光に対しては效果は少 ない232.

\section{4. b Peroxide decomposer}

酸化機棈上から考えて見ると，hpoを分解して不活性 のむのに変えれば目倠酸化が抑制されることは明らかで ある.これについては Kennerly らがよく研究してい る117)。このような作用による酸化防止㓩が Peroxide

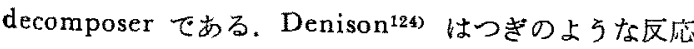
圭認めている。

$$
\mathrm{ROOH}+\mathrm{RSR} \longrightarrow \mathrm{ROH}+\mathrm{R}-\stackrel{\mathrm{O}}{+}-\mathrm{R}
$$

alkyl または phenyl 犆換 mono sulfide の自働酸 化については Bateman の研究がある ${ }^{125)}$.

またつぎのようなイオン的な分解区応も教えられてい る.これは親電子的な弐桬で促進される。

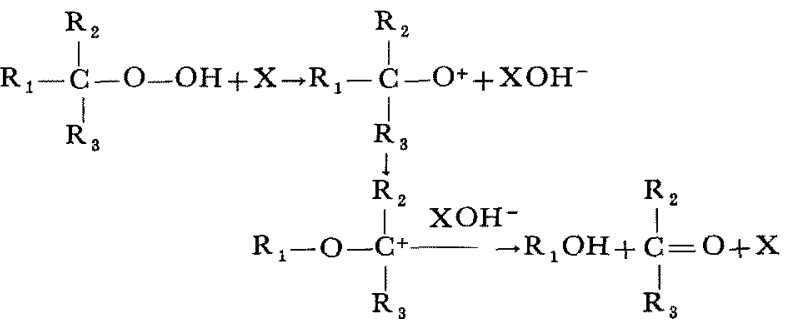

tetraline hydroperoxide はフェ/チアシンで分解 される126)。むたフェノチアシンを cumene hydroperoxide に扣えると，フェノールがよい收率で得られ る.これ䢔酸化物の分解に上述のような機構があるこ とを示瞈するものである.

空気のない場合に Zinc di (4methyl 2pentyl) dithio phosphate t添加して mineral oil $の$ hpoを 分解すると第 4 図のようになる。この分解速度は， hpo に関して一次てある。

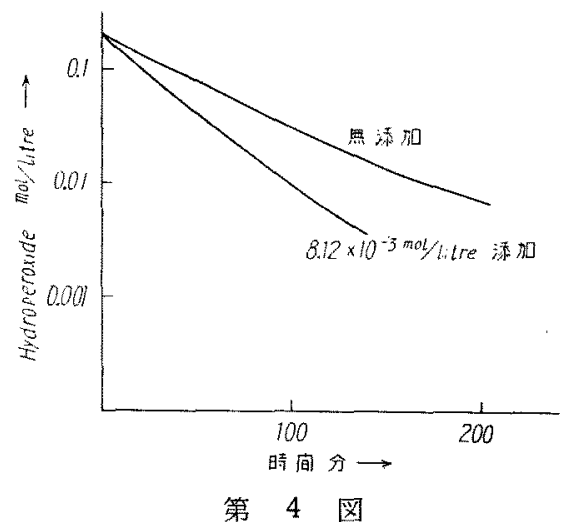

これはinhibitor が hpoの分解を排制して よって酸化防止をするのと刘䟢的てある。

つぎに2，3の簡笚な硫黄化合物による hpoの分解を第 6表に示す。この表に示してある速度常数は次式による ものである。

$$
-\frac{d(P)}{d t}=k(D)(P)
$$

ここに(P)はhpoの濃度，(D)は hpoの decomposer として働らく硫黄化合物の澄度である。 
第 6 表

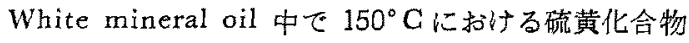
による cumene hydroperoxide の分解速度

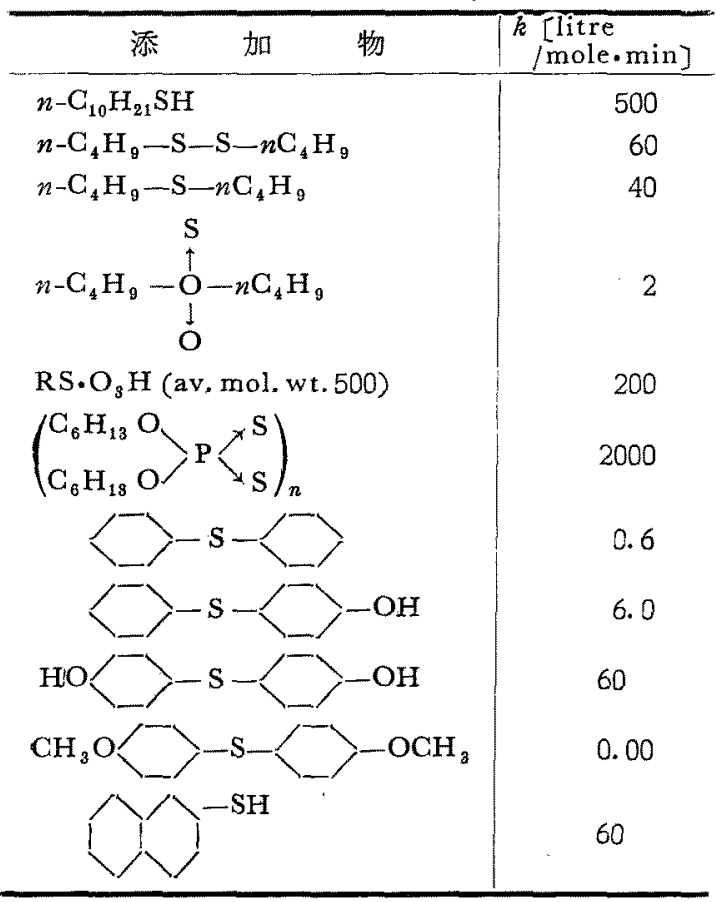

表中 sulfonic acid の活性はその酸性に原因かるる と思放れる。 cumene hydroperoxide の酸による分解 はよく知られているところである

低温に执いては，この分解には induction piriod が 兒られる.そうしてこの期間はラシカルの inhibitorを 加えることによって延長される。

この種の硫黄化合物は初期にhpoで酸化されて，つぎ に分解してその生成物が酸化を防止するもので, 初めの 撒造は活性な酸化防止郕の precurserに過ぎないと考光 られている(29)

メルカプタンに明来する活性の棈造は mercaptyl radical である、こ机はアルデヒドの脱炭酸の触媒であっ て，その中間体はアルデヒドから一電子がメルカプタン に乗り移ると考光られているが，hpoの場合も同様であ ってつぎのうな機情が考えられている。

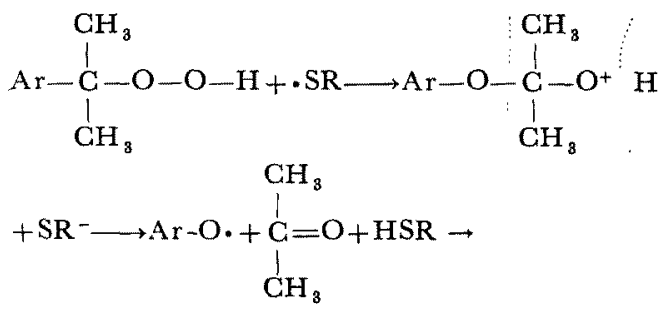<smiles>CC(C)(O)O[Al+2]</smiles>

$$
\mathrm{Ar}-\mathrm{O} \cdot+\mathrm{HSR} \longrightarrow \mathrm{ArOH}+\cdot \mathrm{SR}
$$

phenol sulfide $の$ 場合は electron transfer はつぎ のようにおこる。
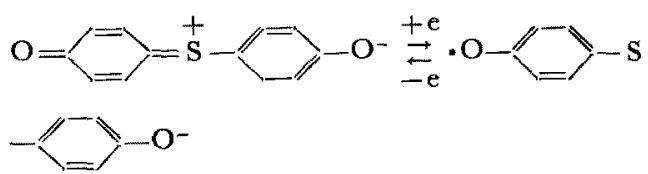

peroxide decomposer の消滅はつぎの反心による.<smiles>CC(C)([R7]O)O[Y17][R7][OH+]C(C)(C)O[Al]</smiles>

このような, peroxide decomposer の存在方場会 の酸化に㧍ける動力学はつぎのよである。今 $\mathrm{P}, \mathrm{D}$, D',をそれぞれ hydroperoxide, peroxide decomposer の原型，ならびにその活泩型とする.

酸化は次式にしたがっておこるものと拷えられる.

$$
\begin{aligned}
& \text { P. } \stackrel{k_{1} a}{\rightarrow} \rightarrow \mathrm{RO} .+\mathrm{HO} .+2 \mathrm{RH} \rightarrow \mathrm{ROH}+\mathrm{H}_{2} \mathrm{O}+2 \mathrm{R} \text {. } \\
& \mathrm{O}_{2}+\mathrm{RH} \mathrm{k}_{1} \mathrm{~b}_{\mathrm{R}}+\mathrm{HOO} \text {. } \\
& \mathrm{R} \cdot+\mathrm{O}_{2} \stackrel{\mathrm{k}_{2}}{\rightarrow \mathrm{ROO}} \text {. } \\
& \mathrm{ROO} \cdot+\mathrm{RH}^{\mathrm{k}_{3}} \rightarrow \mathrm{P}+\mathrm{R} \text {. } \\
& \text { 2ROO. } \quad \mathrm{k}_{4} \rightarrow \mathrm{X} \\
& \mathrm{P}+\mathrm{D} \quad \underline{\mathrm{k}_{5}} \rightarrow \mathrm{Y}+\mathrm{D}^{\prime} \\
& \mathrm{P}+\mathrm{D}^{\prime} \quad \underline{\mathrm{k}_{6}} \rightarrow \mathrm{Z}+\mathrm{D}^{\prime} \\
& \mathrm{P}+\mathrm{D}^{\prime} \quad \mathbf{k}_{7} \rightarrow \text { 不活性生成物 }
\end{aligned}
$$

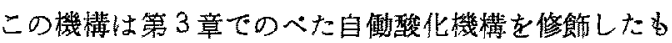
のであるが，酸化防止㰾の存在しない場合には第 3 章に おけると同様な速度式が得られる。すなわち

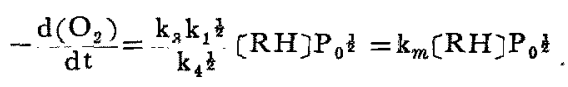

また precurser が消隇するまでの時間を induction period と考岳ればこれは次式で表わされる.

$$
\mathrm{t}=\frac{\mathrm{k}_{5} \mathrm{k}_{6}{ }^{2}}{2 \mathrm{k}_{m}{ }^{2} \mathrm{k}_{1}{ }^{2}} \mathrm{D}_{0}{ }^{2}=\mathrm{k}^{\prime} \mathrm{D}_{0}{ }^{2}
$$

たたし $\mathrm{D}_{0}$ は D の初漶度である。

$\mathrm{D}_{0}$ の霜は $\mathrm{n}$-decyl mercaptane の場合には2であ るが, di n-decyl disulfide の場合には1である。

Peroxide decomposer は上述のような含琉黄化合物暽 
や, dithiophosphate などあるが, mercaptbenzimidazol (MB) bその一種でるといわれているが180)， これについては後述する上うに種々の批判がある。これ は酸化防止剤として有効なものであるがこれを添加して る酸化速度にはあまり変化がなく，相当多量の酸素が老 化を伴わすに吸收される、したがって MBは酸菜の結合 を減少するのではなくて，生成した peroxideを単純な 酸化物に変化するすのであると考光られた。

一方 Le. Foll ${ }^{131}$ は老化時に扎こる忘力緩和の研究か らMBの作用はゴム老化中におこる結合鎖の切断に対応 してさらに架橋をつくり，それによって見掛汁の老北が 防がれているすのだしている。そうしてこれはニトロ 化合物や，リサーシ，また過酸化物のような加硫促進性 のあるものが老化防止作用を示すことがあるのと同じ関 係にあるとしている，MB の覀鉛塩については出化によ っておこる分子鑽の切断に対して新しい架橋を生ぜしめ るむので，すなわち非常に扰そい促進剤であるとする Le Bras の研究がある182).

Shelton ${ }^{12}$ はアミン系の酸化防止剂は運鎖息断剂とし て㗢らくのではくて，過酸化物を促淮する安定㓩であ ると考えている。

\section{4.c Inhibitor}

Inhibitor の作用については多くの研究があり，分子 棈造，物理的特性と作用との関係が明らかにされつつ市 万.

酸化砖元電位はその化合物の分子棈造 ${ }^{133)}$ と密接な関 係があるので，これと酸化防止能との相関関係について の研究がなされている.その結果によれば酸化電圧 0.6 〜0.95Vの範围のものが有効であるといわれる ${ }^{134)}$.

Bolland ${ }^{119)}$ らは過酸化物で initiateした ethyl linoleate の酸化反心において，ハイドロキノンとフェノー ルの誘導体の有する termination の効果と, その酸化 電压の間に直接関係があるとしている，そしてまた電位 が低いほど効果が大であることを見出した ${ }^{1352186) . ~}$

Egloff(a6) らはフェノール系とアミン系の inhibitor の効力について研究し，添加した場合の induction period と酸化電生の関係を調へ，その結果いずれも0.7 ボルト近くにinduction period の極大があり，酸化電 王が1ボルトにす達すると急に能力がなくなってしまう ことをしめした.これはこのように酸化されやすいもの では酸化防止剂自身が酸化されてしまうためである。

Kuzminski137) らはアミンの $\mathrm{N}-\mathrm{H}$ の反応性が酸化防 止作用と関係あるとして各種の二級アミンを用い， 2,2 diphenyl-1-picryl hydrazyl と反応してこれから hydrazineができるモ゙ル反応研究して親電子的基の パラ位の置换が反応性を增加することを認めた。それに よるとつきの賣序である.

phenyl $\beta$ naphthyl amine $<(p-$ methyl phenyl) $\beta$ naphthyl amine $<($ p-methoxy phenyl) $\beta$ naphthyl amine $<$ (p-hydroxy phenyl) $\beta$ naphthyl amine

すなわち右方がもっとも水素を離しやすいるのであ る.

また Na-butadiene ゴムの酸素吸収を研究し同様の 絡論を得ている.すすおわ第二級アミンのパラ位に親電 子的な置換をすると，NHのHがうごきやすくなるから 酸化防止の效果が上ることを認めた：その順位は $\mathrm{OH}>$ $\mathrm{OCH}_{3}>\mathrm{CH}_{3}>\mathrm{H}>\mathrm{Cl}>\mathrm{NO}_{2}{ }^{120}$ であった。

inhibitor の作用としてこれらがゴム分子におよ注す 分子力の大きさによるものであると考えて，分子屈折と 酸菜吸収量の関係定種々の化合物について調べたものが あるが，その関係はあまりはっきりしていない1399。

inhibitor の濃度と，その効果の関係は，濃变と induction period の関係として研究されている ${ }^{108) 117) . ~}$

$2,2^{\prime}$ methylene bis (4-methyl 6 tert butyl phenol)

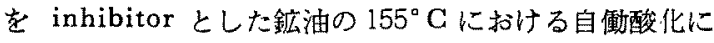
ついては，第5図のようになる。すなわち inhibitor の

第 5 国

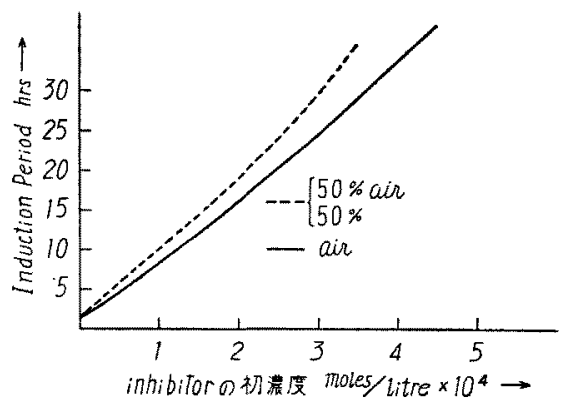

初婊夜が大なるほどinduction period は長くなり，ま た酸素の分圧の低いほど induction period は長くな る. inhibitor の量を第 4 図のものよりもっと增卞と次 第に曲線が㸚てくる，直線関係がどこまでも保持される ものではない.この曲線の权万が低く极るものと高くね るむのとがある.これは inhibitor の濃菨が上ると酸 溸と inhibitorとの直接の反心が增加してくるためであ る.酸素と直接反応しやすいものほど山が低くねる、こ のように inhibitorの量を増加すると，効果がある一定 值に収斂することは既述のように Noyes の实験した scavengerを增加したときの傾问と同じである. 
一航に inhibitor の種類が異なる場合には整案によ る效舆も基なるものてある。 Bickel，Kooyman ${ }^{140)}$ は 2,4,6 rialkylphenol の浼度 (AH) と酸素吸収速度の 関係を調べたところつぎのようにろ種の型があった。今 炭化水素の濃度を（RH）とするとつぎのようになる。

(a) 整度は $(\mathrm{RH}) /(\mathrm{AH})$ に北例する。

(b) (AH) の增加につ扎て酸化速股は極小を通りま た塯大する。

(c) (RH)，拈よび1/(AH) の直線函数て $\{(\mathrm{RH})$ $/(\mathrm{AH})+(\mathrm{RH})\}$ に比例する.

(a) に属するものは 2,4,6tri-tert-butyl-phenol, 2,6 di-tert-butyl 4 methyl phenol, 2 tert-butyl 4,6 di-methyl phenol, 2 tert-butyl 4 methyl phenol.

(b) に属するむのは, 4 tert butyl 2,6 dimethyl phenol, 2, 4 di tert butyl 6 methyl phenol.

(c) に属する蛙，2,4,6 trimethyl phenol, p-tert butyl phenol.

いかなる酸化防止機槛がこ扎らの三理を生じさせるかは 㣪にのベることとする。

加生酸素下に扣いては，inhibitor は非常に酸秦と反 伈しやすなるので，ASTM の䳝䮖法のように $100 \mathrm{lb}$ /in ${ }^{2}$ の酸素分圧で，老化の実験をする場合は酸化反地は 非常に複雑となって空気中に扔ける場合とはかなりの相 暴が予想される。

フェノ一ル品掺体の酸化防止效榡についてはよく研究 されている，置控些と酸化防止効果の間には Hammett の法則が成立している。

Rosenwald ${ }^{141}$ らは，ガソリン中に 100ppm の裴䇣の アルキルフェノールを加えて，その置換基による影薌支

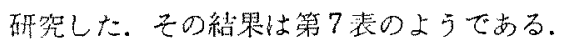

Egloff むガソリン中に0.01\% の各種フェノールを添 扎した場合のinduction period 救好て, 酸化防止能 起研究し第 8 表の結果を得ている。

これらの結果から，フェノールに羁撸するアルキル甚

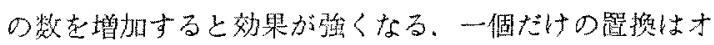
ルト位が效果がある、またオルト位に蕗換するアルキル 基は第三級のbのがもっとも效果がある。

罳換が OHであるフェノ一ルについても同様で，オル 卜置㨨のカテコールがもっと为効果がある。

二個のヘンゼン核を有する biphenyl についてはこ れと買なる絬果が得りれている。

その他，アルキルフェノールについては Wasson, Smithの研究が市り142)，力テコールについては松田 ${ }^{143}$
第 7 表

\begin{tabular}{|c|c|c|c|}
\hline \multicolumn{3}{|c|}{ フェノ一ルの2,4,6位のアルキル基 } & 効 力 \\
\hline $\mathrm{H}$ & $\mathrm{H}$ & $\mathrm{H}$ & 1.5 \\
\hline $\mathrm{Me}$ & - & - & 3.0 \\
\hline - & $\mathrm{Me}$ & - & 4.0 \\
\hline $\mathrm{Me}$ & $\mathrm{Me}$ & - & 20.5 \\
\hline $\mathrm{Me}$ & - & $\mathrm{Me}$ & 15. 0 \\
\hline $\mathrm{Me}$ & $\mathrm{Me}$ & $\mathrm{Me}$ & $57.0^{\circ}$ \\
\hline$n-B u$ & - & - & 6.5 \\
\hline$i-B u$ & - & - & $5.0^{\prime}$ \\
\hline $\sec -\mathrm{Bu}$ & - & - & 5.5 \\
\hline$t-B u$ & - & - & 10.5 \\
\hline - & $\mathrm{n}-\mathrm{Bu}$ & - & 3.5 \\
\hline 一 & $\mathrm{i}-\mathrm{Bu}$ & - & 2.0 \\
\hline - & $\sec -B u$ & - & 2.0 \\
\hline - & $\mathrm{t}-\mathrm{Bu}$ & - & 3.5 \\
\hline $\mathrm{Me}$ & - & $n-B u$ & 13.5 \\
\hline $\mathrm{Me}$ & - & $\mathrm{i}-\mathrm{Bu}$ & 18.5 \\
\hline $\mathrm{Me}$ & - & $\sec B u$ & 15.5 \\
\hline $\mathrm{Me}$ & $\mathrm{n}-\mathrm{Bu}$ & - & 15.0 \\
\hline $\mathrm{Me}$ & $\mathrm{i}-\mathrm{Bu}$ & - & 12.0 \\
\hline $\mathrm{Me}$ & $\mathrm{sec}-\mathrm{Bu}$ & - & 8.5 \\
\hline $\mathrm{Me}$ & $t-B u$ & - & 14.5 \\
\hline$n-B u$ & $\mathrm{Me}$ & - & 19.5 \\
\hline $\mathrm{i}-\mathrm{Bu}$ & $\mathrm{Me}$ & - & 18.5 \\
\hline $\sec -\mathrm{Bu}$ & $\mathrm{Me}$ & - & 27.5 \\
\hline$t-B u$ & $\mathrm{Me}$ & - & 37.5 \\
\hline $\mathrm{Me}$ & $\mathrm{Me}$ & $n-B u$ & 46.5 \\
\hline $\mathrm{Me}$ & Me & $\mathrm{i}-\mathrm{Bu}$ & 57.0 \\
\hline $\mathrm{Me}$ & $\mathrm{Me}$ & $\sec B u$ & 51.0 \\
\hline $\mathrm{Me}$ & $\mathrm{Me}$ & $\mathrm{iBu}$ & $100.0^{\prime}$ \\
\hline $\mathrm{Me}$ & $\mathrm{t}-\mathrm{Bu}$ & $\mathrm{Me}$ & 18.5 \\
\hline$t-B u$ & $n-B u$ & - & 42.0 \\
\hline$t-B u$ & $\mathrm{i}-\mathrm{Bu}$ & - & 29.5 \\
\hline$t-B u$ & sec-Bu & - & 27.5 \\
\hline$t-B u t$ & $t-B u$ & - & 33.0 \\
\hline$t-B u$ & $t-B u$ & $\mathrm{Me}$ & 42.5 \\
\hline $\mathrm{t}-\mathrm{Bu}$ & $\mathrm{Me}$ & $t-B u$ & 76.0 \\
\hline $\mathrm{t}-\mathrm{Bu}$ & $\mathrm{t}-\mathrm{Bu}$ & $t-B u$ & 39.5 \\
\hline
\end{tabular}

第 8 表

\begin{tabular}{|c|c|c|c|c|}
\hline \multicolumn{5}{|c|}{ Induction period $(\min )$} \\
\hline phenol & \multicolumn{3}{|c|}{ n-butyl phenol $(o+p)$} & 195 \\
\hline$o$-cresol 135 & \multicolumn{3}{|c|}{ t-butyl phenol } & 210 \\
\hline$m$-cresol 75 & \multicolumn{3}{|c|}{$\alpha$-naphtol } & 2,250 \\
\hline$p$-cresol 210 & \multicolumn{3}{|c|}{$\beta$-naphtol } & 330 \\
\hline \multicolumn{4}{|c|}{1,5 dihydroxynaphthaline } & \\
\hline \multicolumn{2}{|c|}{ o-hydroxy biphenyl } & & 60 & \\
\hline \multicolumn{2}{|c|}{ p-hydroxy biphenyl } & & 135 & \\
\hline \multicolumn{2}{|c|}{2,4 dimethyl phenol } & & 420 & \\
\hline \multicolumn{2}{|c|}{2,6 dimethyl phenol } & & 255 & \\
\hline \multicolumn{2}{|c|}{2,5 dimehtyl phenol } & & 285 & \\
\hline catecol & resorcin & & 150 & \\
\hline dibutyl resorcin & 360 & dihexyl re & esorcin & n 390 \\
\hline hydroquinone & 85 & pyrogallol & & 2,185 \\
\hline
\end{tabular}


の研究がある。

Wasson らは潤滑油中にアルキルフェノールの0.1wt \%を添加し空気を通じて加䓡酸化しその時の酸洒の上昇 を測定した．酸化は初めの間は上昇しないが，ある時間 過ぎると急激に上昇してくる。この時間を induction period とし, これの長短から打の拉ののアルキルフェ

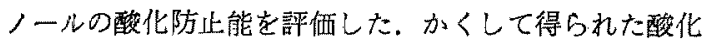
防止の能力の順位は必しる, 先の Rosenwaldのむのと 一致していない。

2,4 xylenol の6の位置に置換した場合の置換基の影 響をつぎに示す（第 9 表参照)

第 9 表

\begin{tabular}{|c|c|c|}
\hline & $\mathbf{R}$ & $\begin{array}{l}\text { Induction } \\
\text { period (時間) }\end{array}$ \\
\hline $\mathrm{OH}$ & $\mathrm{H}$ & 72 \\
\hline $\mathrm{CH}_{8}$ & $\mathrm{CH}_{3}$ & 72 \\
\hline & $\left(\mathrm{CH}_{3}\right)_{2} \cdot \mathrm{CH}_{2}$ & 72 \\
\hline & n-Butyl & 72 \\
\hline & sec-Butyl & 150 \\
\hline $\mathrm{CH}_{3}$ & tert-Butyl & 250 \\
\hline
\end{tabular}

各種の化合物についての，アルキル基の效果を第10表 に示す

第10表からつぎのことが認められる.すなわち 2 と 6 の位㯰に tert-Bu基のあるものがもっともよく，4の位 置のメチルは sec あるいは tert の基で置換すると効果 が执らる．しかしながら，4の位置を $\mathrm{C}_{2} \mathrm{H}_{5}$ とか $\mathrm{n}$ butyl とかで置換すると，それぞれ induction period が500時間とか575時間となって極めて有效である。

これらの結果は，Rosenwaldらが，たと壳ば2,4 di methyl 6 tert-butyl phenol 力 $^{5} 2,6$ tert-butyl 4 methyl phenol より有効であるとした結果と一致しな いが，これは自働酸化に供試した陚料とその効果の解析 の方法の相異によるむのであるう。

多くの結果からもわかるように酸化防止作用の強いと 思われるフェノールはいわゆる hindered phenol であ る.

Boozer, Hammoud ${ }^{145)}$ らの研究によれば, クメンお よびテトラリンのクロルベンゼン溶液中に各種の inhibitor とくにフェノール類ならびにモノメチルアニリン の各種置換体を添加してその効果を測定した，その相対

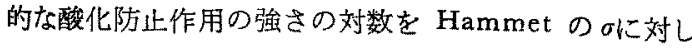
て図示すると第6図のようになり直接関係が得られ，そ の直線から $\rho=-3.7$ であることが知られる。

このように犆換基と酸化防止作用との間に妒 Ham-

(75)
第 10 表

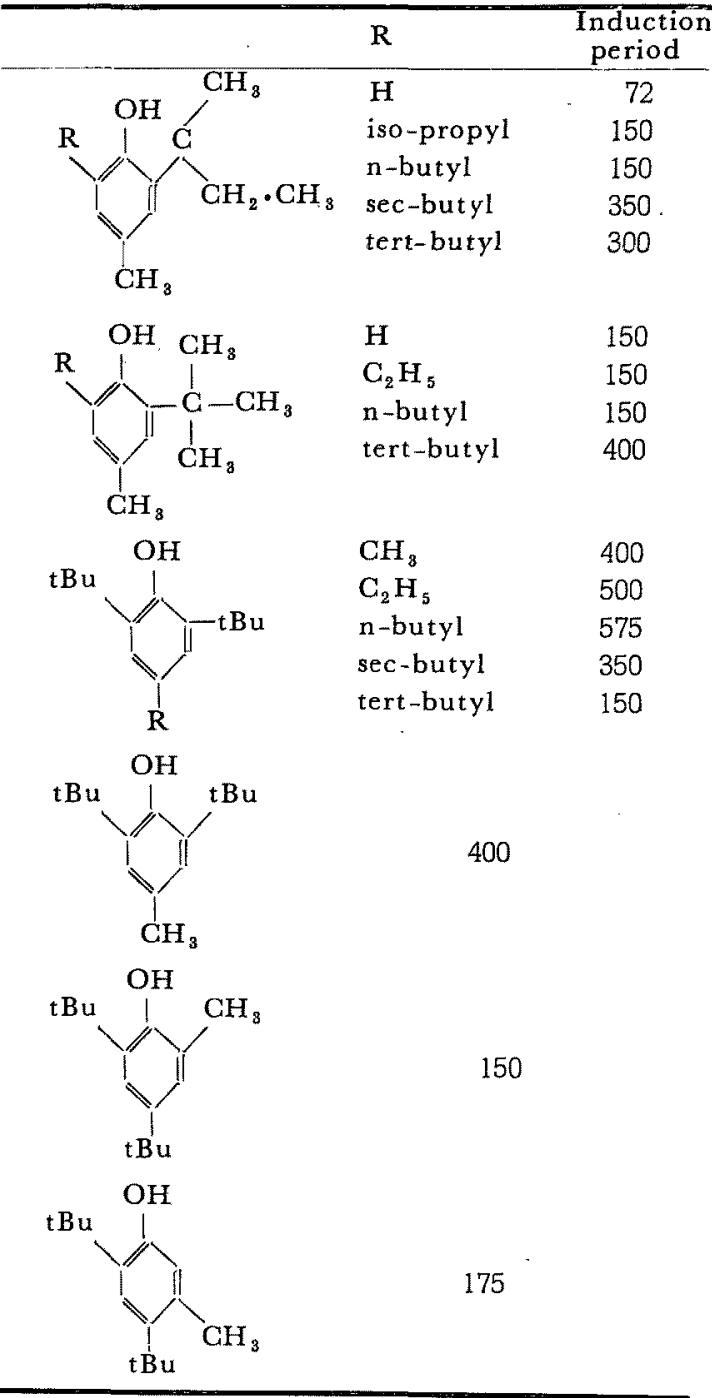

mett の法則が成立っている.すなわち電子供給性の置 換基を有するものは酸化防止作用が大で，電子吸収性の 罟換基は防止効果を隇少させる.一般に電子供給基はフ ェノールの酸化電位を低下せしめ, 逆に電子吸引基は電 位を高める。この事実は既述の通り Eglof，Lowry ら がすでに認めたところである。

置換基の効果に関しては inhibitor から生成するラシ カルが置換基の存在によって安定化されるためだという 考えがある146).フェノールの場合にはつぎの反応で生 じるラジカルが置換基のある場合には非常に安定なセミ キノン型となるので，むはや連鎖反心にあずからなくな るのである４４位のメチル基がそれ以外の大きな置換基 


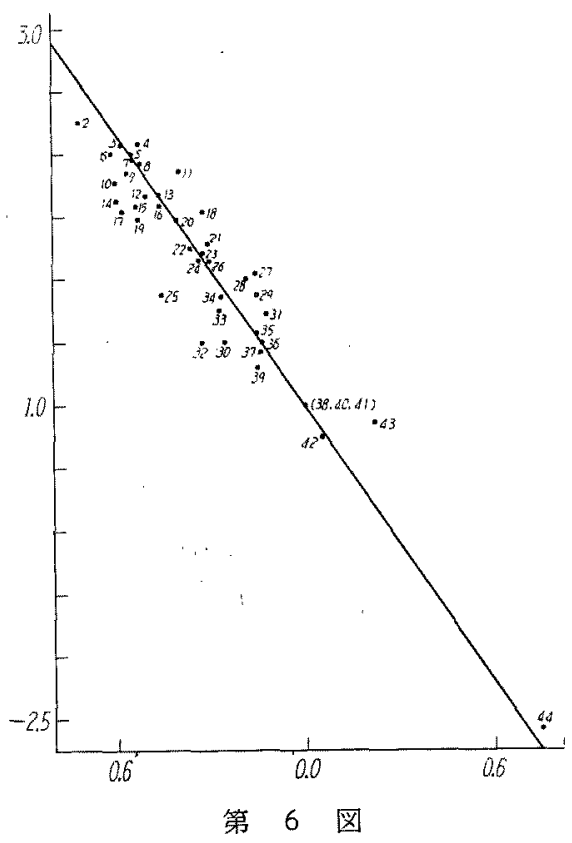

1. 1,4 naphthohydroquinone; 2. 2,3,5-trimethylhydroquinone; 3. N-(2-butyl)-4-aminophenol; 4. 3n-dodecylcatechol; 5. 2,4-dimethyl -6-t-butylphenol; 6. 2amino-4-phenylphenol; 7. pyrogallol; 8. 4-t-butylcatechol; 9.2,6-dit-butyl-4-methylphenol; 10. 2-t-butyl-4methoxyphenol; 11. 2-phenol-hydroquinone; 12. 2,4,6trimethylphenol; 13. 2,4-dimethyl -6-alkylphenol; 14. 1-and 4-aminopherols; 15.2,6 dimethoxyphenol; 16.toluohydroquinone; 17. 2,4,6-tri-t-butylphenol; 18. 2-t-butyl-4alkylphenol; 19. 2,4 di-t-6methylphenol; 20. hydroquinone; 21. 2alkyl-4methylphenol; 22. catechol; 23. $\alpha$-naphthol; 24. 2,6-and2,4dimethylphenols; $25 . \quad \mathrm{N}, \mathrm{N}^{\prime}$-diphenyl-pphenylenediamine; 26. 2-methyl-6alkylphenols; 27. 2methyl-4-alkylphenols; 28. 2-t-butylphenol; 29. 3 aminophenol; 30. 4 methoxy diphenylamine; 31. 2-alkylphenols; 32. 4hydroxydiphenylamins; 33. 4-methoxyphenol; 34. 4-methoxy-N-methylaniline; 35. 2-and 4-methylphenol; 36. 4alkylphenols; 37. Bnaphthol; 38. diphenylamine; 39. 4-methyl-Nmethylaniline; 40. phenol; 41 . n-methylaniline, 42. resorcinol; 43. 4bromo- $\mathrm{N}$-methylaniline; 44. 4nitro-N-methylaniline.

より有効であるのは,メチル基の hyper conjugation による生成基の安定化のためとる説明されているがこれ は Wasson, Smith ${ }^{1422}$ の 4 位はnーアルキル基の大なるも のほどよいという絓果と一致していない，酸化防止機糡
は次式のようであって，生成する ArO・ラジカルの安定 化はつぎのようである.

$\mathrm{ROO}+\mathrm{ArOH} \longrightarrow \mathrm{ROOH}+\dot{\mathrm{r} O} \mathrm{O}$.

$\mathrm{ArO}$ - の安定化に役立つ安定なセミキノン型の共鸣棈 造はつぎのようなものである。<smiles>[R]c1cc([R])c([O])c([R])c1</smiles><smiles>[R]C1=CC([R])C([R])C1=O</smiles><smiles>[R]C1=CC([R])C(=O)C([R])=C1</smiles><smiles></smiles>

これら安定な Aryloxy ラジカルと不飽和化合物との 反応についてす研究されているか，Aryloxyラシカルは hindered phenol を酸化剮で酸化して生成させたもの を用いている(14).

しかるに p-phenylene diamine 系のものではル 卜位のアルキル置換は共鳴を此めてしまうのでしたが ってセミキノン型の窒素克含もラシカルむ生じなくなる から酸化防止作用が減殺されてしまう ${ }^{148)}$ 。

ガソリン中に扩ける芳香㵀アミンの各種圈換体の酸化 防止作用の強さはPederson年9) に上って研究された。 そ の結果を第11表に示す。

この表からも，電子供給基は酸化防止能を高めるし， またNーCのような電子吸引基は低下させることが知ら れる、しかしながら他の例では空間䌖造も一要因であっ て，障害のあるものの方が効果が大である、これは立体 障害のないものは他の反応で消滅しやすいためであろ 5.p-phenylene diamine において，置換基に二種あ るものては低い方の值が得られている。

パラアミノフェノールでは，空素の置換基をかえてる あまり変化がないが，一OH——OR とすると作用が なくなる。これは次式に示すような水素の脱離がこの際 必要であるからであろう。

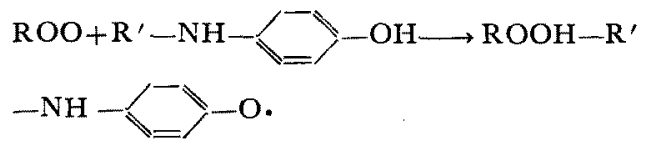

Kuzminskii らは先にのベたように二級アミン類から の水菜のとれやすさの順位をきたが，これを添加した ゴムの modulus の测定と水絜のとれやすさの順位は平 行関係にあることを見出し，つぎの反応段階が inhibi- 
第 11 表

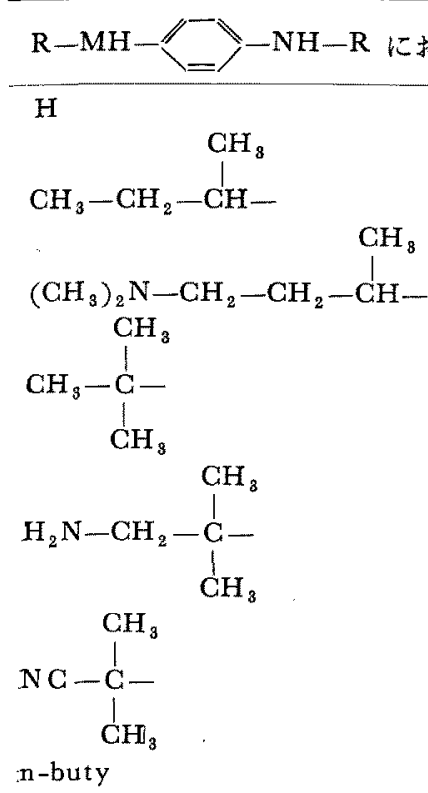

$\mathrm{CH}_{8}-\mathrm{CH}_{2}-\mathrm{CH}_{2}-\mathrm{CH}_{2}$

$=-\mathrm{CH}_{2}-$<smiles>CC1(C2CCCCC2)CCCCC1</smiles><smiles>CCC(C)C</smiles><smiles>CCC(C)C</smiles><smiles>[R]Nc1ccc(O)cc1</smiles>

$\mathrm{H}$

n-butyl

$\mathrm{CH}_{3}-\mathrm{CH}_{2}-\mathrm{CH}_{2}-$<smiles>CCC(C)C</smiles>

tor の作用する段階であるとした．

$$
\mathrm{ROO}+\mathrm{AH} \longrightarrow \mathrm{ROOH}+\mathrm{A} \text {. }
$$

酸化防止剂の作用機棈を調べるには，重水菜置換体を 用いて水菜が反応にあずかる段階を浮き彫りにして見る ことは有力な方法である。

Inhibitor の作用機楆については上述のように種々の 点から芳香族アミンのアミノ基の水素あるいはフェノ一 ルの水酸基の水案またはオルト位の水素などが反心にあ すかるのではないかと思われている。すなおち, hydroperoxy radical が, hpoになる段階の反心連鎖を切断 すると思われている。この水䒺の関与する段階が律速段 階であるならば，この水菜を重水紮で置換したものでは 酸化防止効果が異なるはずである。

J.R. Shelton ${ }^{150)}$ bは SBR の酸化防上戍としてアミ ン類, フェノール類の効果を重水菜置換したものと此較 した. 用いたものは 2,6 di-t-butyl 4 methyl phenol; $\mathrm{N}$-phenyl 2 naphthyl amine の水素を重水素て交換 したものである.そうしてこの inhibited oxydation の 律速段㫮は ROO. に水絜をあたえるところであるとの ペている。

Walling ${ }^{1512}$ らは, 過酸化物とフェノールの反心をモデ ル的に研究したか， o-deuterated phenol を用いた場 合の過酸化物の分解速度は軽水菜の場合の速度恒数と比 較すると、つぎのようにわずかの効果がある、すなわら $\mathrm{k}_{H} / \mathrm{k}_{D}=1.32 \pm 0.03$ である.

また立体障害の効果のあること，ならびに水素結合を 作る溶媒では溶媒効果が表われることから，律速段階お よびその前後の平衡に $\mathrm{OH}$ 基が直接関与している反応が あることを推論した。これに反してアミンの場合の二， 三の笑験に打いてはいずれも同位元素效果を認めていな W.

G.S.Hammond ${ }^{145)}$ 5は diphenylamine $と$ N-Ddiphenylamine ならびに N-D-N rethyl aniline methyl aniline とをテトラリンの自衝酸化のinhibitor として用いた場合何ら差のないことを認めた。

またC、J. Pederson ${ }^{1497}$ は N N' diphenyl-p-phenylene diamine $\prec N D N^{\prime} D$ diphenyl $p$-phenylene diamine をテルペンに0.000066 mols/litre 〜 0.050264 mols/litre の戀度で加えてinduction period を調へた が何ら同位元㐿効果を認めなかった。

これらのことから後に退ぺように Hammond や Pedersonはそれぞれ錯化合物の生成や peroxy anion

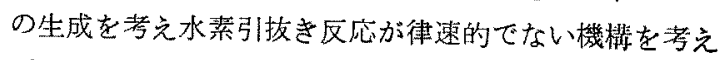
ている。 
しかるに既にのヘた Shelton 2033 らの実験によれば， NDN phenyl 2 naphthyl amine $と$ O-D-2, 6di tert butyl 4 methyl phenol をつくり，これとD置換のな いものとの酸化防止作用を $\mathrm{SBR} の \mathrm{O}_{2}$ の吸收速度を $90^{\circ} \mathrm{C}$ で測定して抢のおのの速度恒数を求めて見ると， $\mathrm{k}_{D} / \mathrm{k}_{H}$ は 77\% D 化した phenyl 2 naphthyl amine では1.8 であり，60\%D 置換した後者のフェールでは1.3とな り，いずれも重水沶化によって酸紫吸収の速度恒数が大 となる。すなわち重水亲化した多のは酸化防止作用が弱 いことを認め，水素引き拢き反応が律速的であううとし ている，また被らは活泩な水桑のない第三級アミンなど ではHammond または Pederson の見解を支持してい る. Shelton の实験を行なったのは，SBR の固体で あり，Hammondらはクメン，Pedersonはガソリンを 対象に選んでいる相異はあるが，Sheltonは Hammond らの实験成績にも同位元素效果は認められるといってい る.しかし Shelton の行なった害験で闰位元素效果の 認められるのはコムに対して $3 \%$ 混合した時で，1％混 合では認められない、これいついて彼の見解は1％では inhibit されない自㗢酸化の部分が早く現われてくるた めに差がなくなるのだろうといっている，以上種々の研 究台ら inhibitor の作用段階に水素があすかっているか どうかは後に述へることとして一方加えられた酸化防止 剂が酸化によってどう変化して行くかはこの作用機棈を 調べる手がかりになる．酸化防止刱の変化については先 に peroxide decomposer の場合についてのべたが, inhibitor の場合にも種々研究されている.

アルキルフェノールを添加した場合の自働酸化によっ て生じる化合物については Water らによれぱつぎのよ うである。

$p$-cresol でクメンの酸化防止をしたさいにはつぎの biaryl 型の二量体となる.

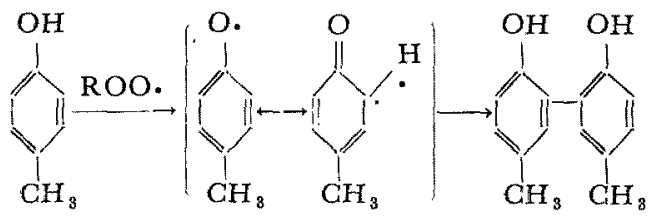

2.6 位に㽡掺のある hindered phenol では, dibenzyl 型の二量体を経て stilbenquinone が得られる。<smiles>[R]c1cc(CI)cc([R])c1O</smiles><smiles>[R]c1cc([R])cc(CCCc2cc([R])c(O)c([R])c2)c1</smiles><smiles>[R]C1=CC(=CC=C2C=C([R])C(=O)C([R])=C2)C=C([R])C1=O</smiles>

2,6 dimethyl phenolを用いたモデル実䮑ではこれを benzoyl peroxide で酸化してつぎのものを得ている,

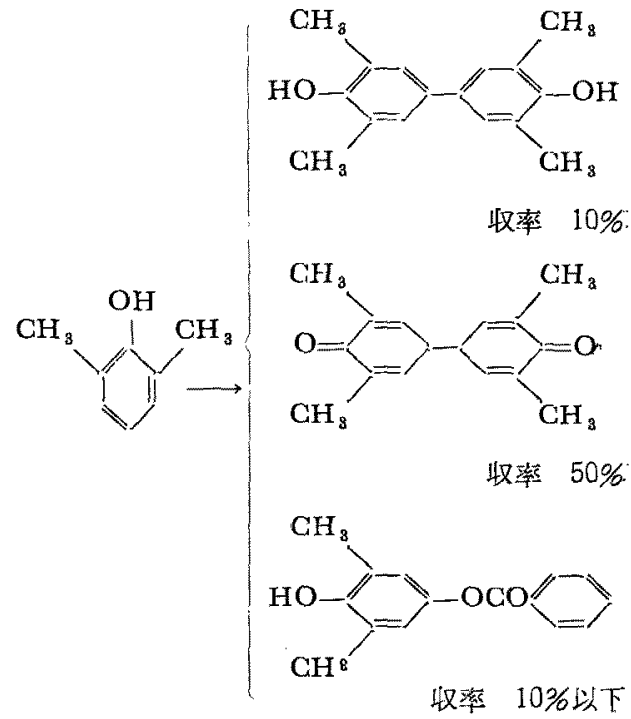

このような生成物をあたえる反坎はつぎのように進行 する。

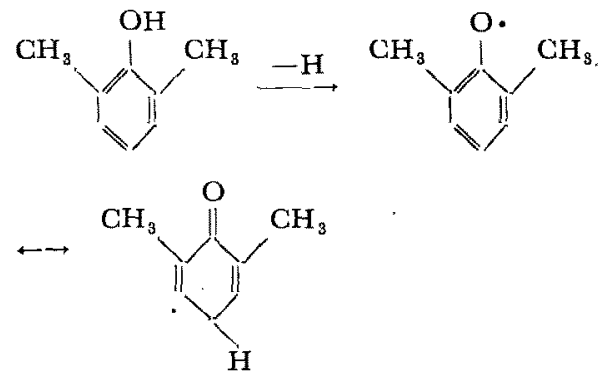

なお種々の位圆に置換基のするフェノールを Benzoyl peroxide で酸化したモデル実験によるとつぎのようで ある。

(1) オルト位の空いているフェタ一ル雄らは， catechol benzoate が生じる. 


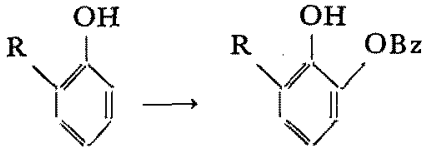

またはクレゾール $\overline{\mathrm{BzO}}_{2}$ (catechol monobenzoate ${ }^{149)}$, lactone of $o$ $\left\{\begin{array}{l}\text { hydroxy phenyl acetic } \\ \text { acid }\end{array}\right.$<smiles>CC1=CC(=C2C=C(C)C(=O)C(C)=C2)C=C(C)C1=O</smiles>

$333^{\prime} 3$ ' tetramethyl dibenzoquinone

(3)<smiles>CC1=CC(C)(C(=O)c2ccccc2)C=C(C)C1=O</smiles>

$2,4,6$ trimethyl 4 benzoyl oxy cyclohexa 2,5 dienone.

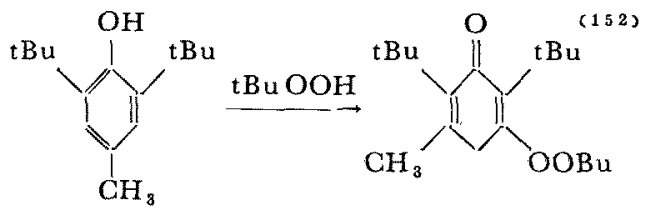

4 位に置換基のない場合には，酸化剤としての過酸化 物の種類を変えても，反念生成物は主として， dipheno quinone であるし，また他の位置の置換基が変っても 同倳である。<smiles>[R]C1=CC(=C2C=C([R])C(=O)C([R])=C2)C=C([R])C1=O</smiles><smiles>CC(C)c1cccc(C(C)C)c1O</smiles><smiles>COc1cccc(OC)c1O</smiles>

これらの生成の袎秷に関し， C. Wallingis1) らは上 述の Cosgrove らのラシカルを含さ機構に反し，また Hammond ${ }^{145)}$ らのフェノールと過酸化物との錯化合物 の生成を批判してつぎのような Claisen 反応類似の機样 を提出した。

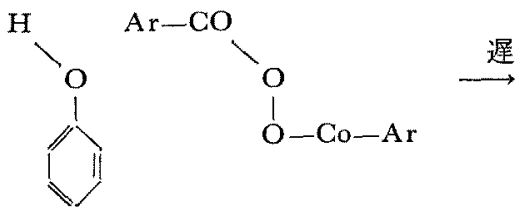

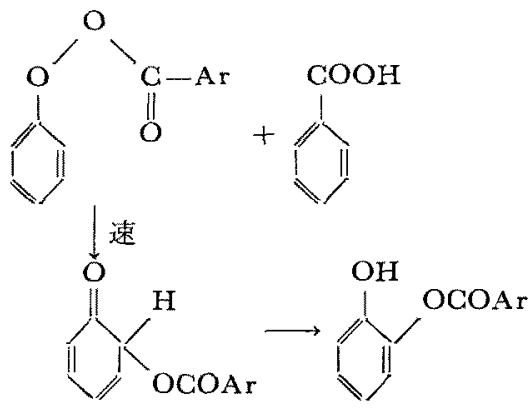<smiles>[Y19]C(=O)OOc1c([R])cccc1[R]</smiles><smiles>[R]C1=CC(c2cc([R])c([OH+]C(=O)[O-])c([R])c2)C=C([R])C1=O</smiles>

しかるに Batten ${ }^{153)}$ らはこの反応にラシカルの中 間体を考えている。

その他フェノールとalkyl peroxy radicalとの反心生 成物について, Bickel らの研究がある ${ }^{154)}$ 。

メントールの場合は前記と同様な機構によってつぎの 生成物をあたえる。

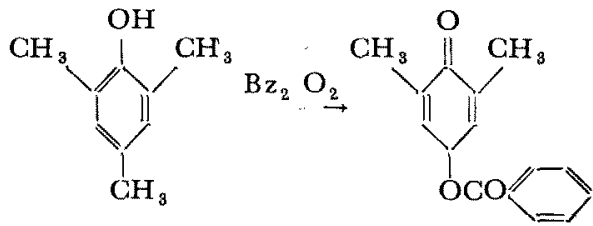

收率 $90 \%$ 
<smiles>CC1=CC(=CC=C2C=C(C)C(=O)C(C)=C2)C=C(C)C1=O</smiles>

微量

また2,6 di-t-butyl $p$-cresol と $\mathrm{tBuOO}$ との反心 生成物すつきの型の处ので上述と同じことが予想される 152)。また，これが酸化して二量体が生成する ${ }^{155)}$.<smiles>CCCCOC1=C(C(C)(C)C)C(=O)C(C)=C1C</smiles>

ハイドロキノンの場合はつぎのようになる゙19.

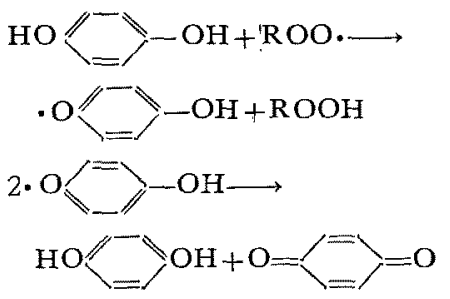

アミン系の酸化防止郕についてはP.Schneider ${ }^{214)} の$ 研弩がある.フェノールの場合にはその非，置換基の位 置，数によって種々のものができた。

Diphenyl amine を二酸化マンガンで酸化すると， $\mathrm{NN}^{\prime}$ diphenyl benzidine $\varepsilon$ quinone dianil $か ゙$ 生 じる、また， リで酸化すると $\mathrm{NN}^{\prime}$ tris $\beta$ naphthyl $1,2 \mathrm{Na}-$ phthylene diamine ができる。

加㱩ゴム中に混合した場合は酸化生成物は溶解度の減 少によってゴムの表面に出てくるのでこれを分析した。 その結果 N-phenyl $\beta$ naphthyl amine t含むもの て $N^{\prime}$ diphenyl-N-2-naphthyl 1,2 naphthylene diamine が認められる。 また diphenyl amine を含む ものからは NN' diphenyl benzidine が楒められた。

つぎに inhibit された酸化反応の機棈について述へ 3.

まず N-phenyl 2 naphthyl amine を用いて行なつ た酸化反心では， initiation の活柱化工ネルギーは22. $\mathrm{kcal} / \mathrm{mol}$ でこの值はどんな+゚リマーについても共通で ある。（ただし electronegative な监換基のないるのに ついである.）たポリイソブチレンでは $\mathrm{N}$ phenyl 2 naphthyl amine がある裂变以上に存在すると initiation は招こらない214).

Inhibit された反心の動加学については Shelton*1)

らの研究があるが，彼の考えによればつぎのようであっ て，その機桡はつぎの実䮖事実を説明できなければなら th:

（1）酸化防止剂の添加量には最有效濃菨がある。

(2) フェノール系酸化防止剤とアミン系のそれとの効 力口差.

（3）酸化防止剂の相乗作用.

（4）暗所において酸化防止作用を有する物質が光增 感酸化を促進する。

（5）純ゴムとカーボン配合のゴムに㧊ける酸化防止郕 の効果の差.

これを説明するためにつぎ機掅が考えられた。

Initiation:

(a) 過酸化物の分解 $\mathrm{xROOH} \stackrel{\text { 至 }}{=} \mathrm{nR}$. (RO. , ROO.)

(b) 炭化水素の酸素による直接の攻㢣: $\mathrm{RH}+\mathrm{O}_{2} \stackrel{\mathrm{k}_{1}{ }^{\prime}}{\longrightarrow} \mathrm{R}$.

(c) 酸化防止剂と酸素との反応: $\mathrm{AH}+\mathrm{O}_{2} \stackrel{\mathrm{k}_{1}{ }^{\prime \prime}}{\longrightarrow} \mathrm{A}$.

Propagation:

(d) $\mathrm{R} \cdot+\mathrm{O}_{2} \stackrel{\mathrm{k}_{2}}{\rightarrow} \mathrm{ROO}$.

(e) $\mathrm{ROO} \cdot+\mathrm{RH}^{\stackrel{\mathrm{k}_{3}}{\rightarrow}} \mathrm{ROOH} \cdot+\mathrm{R}$.

Chaintransfer:

(f) 酸化防止削の関与: ${ }^{1572} \mathrm{ROO}+\mathrm{AH}_{-}{ }^{\mathrm{k}_{4}}$ $\mathrm{ROOH}+\mathrm{A}$.

(g)

$\mathrm{A} \cdot+\mathrm{RH} \stackrel{\mathrm{k}_{5}}{\rightarrow} \mathrm{AH}+\mathrm{R}$.

Thermination:

(h)

(i)

(j)

\section{過酸化物の分解:}

(k) 酸化防止浏によって誘発された分解:

$$
\mathrm{xROOH} \stackrel{\mathrm{k}_{a}, \cdot \mathrm{AH}}{\rightarrow} \text { 安定生成物 }
$$

この機棈をるとにすると，次式が導かれる。

$$
-\frac{\mathrm{d}\left(\mathrm{O}_{2}\right)}{\mathrm{dt}}=\mathrm{K}_{0}\{\alpha(1+\sqrt{1+\beta \mathrm{P}}+\gamma \mathrm{P}\}
$$

となり， $\gamma \mathrm{P}$ が小さいときは酸素吸収速度は $\mathrm{P}$ 至に比例す 
るという寒験結果と一致している.

また動力学的な考察か，フェノールはchain transfer には，アミンより劣るが， termination にはアミンよ

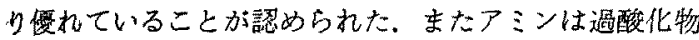
を分解してしまってinitiation にあずからなくするもの と思われる.一方フェノールはこれに対して無力である から，その酸化防止効果はアミンに劣るものである.

アミンはこの見解からはperoxide decomposer であ るが，その過酸化物を分解する反応はつきのことともの であると侾えられている。

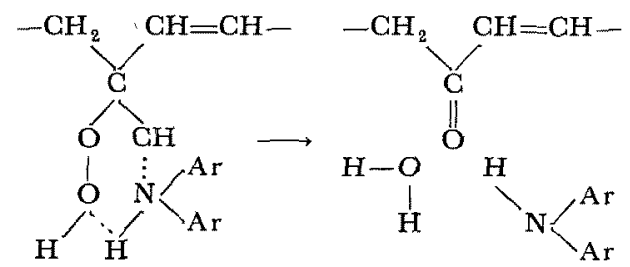

カーボンブラックは過酸化物がラジカルヘ分解するの を促進するから，カーボン配合ゴムでは酸素の吸收が速 くなる．純ゴムではカーボン配合のよきよりフェノール がより効果的になるのは，フェノールは termination に効果がありアミンは過酸化物の分解に効果があるため であるこの見解はアミン系の酸化防止剖には同位元絮 効果がなくフェノール系には同位元素効果があることと 一致している。

一方酸化防止剂の量を堌大すると，酸素が直接的に防 止剂を攻慗して，これが連鎖の initiator となって行く ために却って效果が抬るるのである。

さてこのようにフェノールはtermination にはアミン より效果があるが，両者を併用すれば両方の作用段階 で，酸化反応を拊制するから相乗效果が表われる。

光增感酸化の場合には䀧所では chain transfer の みが問題となり，明るいところては，つぎのよう酸化 防止㰾自身の分解吕括こる。

$$
\begin{aligned}
& \mathrm{AH}^{\mathrm{h}} \mathrm{h} \nu \longrightarrow \mathrm{A}^{*} \\
& \mathrm{~A}^{*}+\mathrm{RH} \longrightarrow \mathrm{AH}+\mathrm{R} .
\end{aligned}
$$

Phenyl $\beta$ naphthylamine には紫外部に特有の吸收 がある、このように光は酸化防止剤分解消隇させるか またはこれから酸化の反应連鎖が始まるので，いずれに 女上酸化防止剂の効果は減殺される。

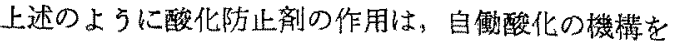
もとにして説明されるが, Bolland，TenHane ${ }^{119}$ む hpoの連銧機棰で説明している.

Walling ${ }^{1-a)}$ は第二章に述べた酸化機樍において酸化
防止用の作用による機棈をつぎの二つであるとして論じ ている.

ROO. + Inhibitor $\stackrel{\mathrm{k}_{i n} \rightarrow \text { Inactive Product (4d1) }}{ }$

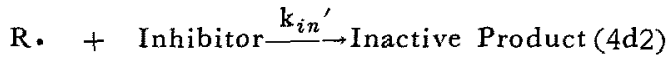

(4d1) によると酸素圧の高いときは酸化速度は次式で 表わされる。

$$
-\frac{\mathrm{d}\left[\mathrm{O}_{2}\right]}{\mathrm{dt}}=\frac{\mathrm{R}_{i} \mathrm{k}_{3}[\mathrm{RH}]}{\mathrm{nk}_{i n}[\ln \mathrm{n}]}
$$

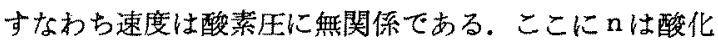
防止剂 1 モル当り停止される連鎖の数である。

Inhibit されている反心の速度をRとしinhibitされ ていないときの反応速度を $\mathrm{R}_{0}$ とすれば，その比は次式 で表わされる。

$$
\frac{\mathrm{R}}{\mathrm{R}_{0}{ }^{2}}=\frac{2 \mathrm{k}_{6}}{\mathrm{nk}_{\mathrm{8}} \mathrm{k}_{\text {in }}[\mathrm{RH} H \overline{[\operatorname{lnh}]}}
$$

(4d2)は，initiation で生じたラシカルをつぎの酸索 吸收の反応を起す前に不活性化してしま扣うとするもの であるか，これを仮定すると次式を得る。

$$
\frac{\mathrm{R}}{\mathrm{R}^{2}{ }_{0}^{-}}=\frac{2 \mathrm{k}_{0} \mathrm{k}_{6}\left[\mathrm{O}_{2}\right]}{\mathrm{nk}_{3}{ }^{2} \mathrm{k}_{i n^{\prime}}[\mathrm{Inh}][\mathrm{RH}]^{2}-}
$$

実験的には (4d4)が成立している。すなわち酸化防止 郕の效力は酸絮圧に無関係であるから, inhibitor は peroxyradical と反応して連鎖停止を行なうむのである 154).

Lかし 3,5, 3', 5'-tetra methyl 4, 4'-diphenoquinone で, benzaldehyd の自働醉化を抑制した場合 には炭化水絷ラジカルが不活性化される ${ }^{158)}$.

Bolland らは, peroxyradical はフェノールやアミ ンの中の质性な水素と作用すると考克ている。

これに対し，Hammond らはつぎのように必ずしも 水菜のあずからない機構を多くの军䮖事実から述べてい る。それによればつきのようである。

Hammond ${ }^{1452}$ bは azo bis iso butyro nitrile (A IBN)で initiate した岸化水素の酸化において一般に 認められているつぎ機槛における酸化防止用の作用を (4d12)、すなわら hydroperoxyradical の不活性化と して教えた。
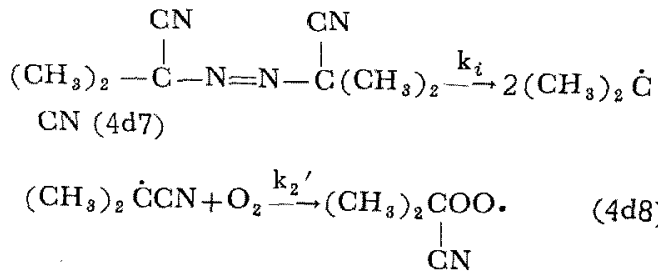
<smiles>[R]OC(=O)CCC([R]POC(C)(C)C#N)C#N</smiles>

$\mathrm{R} \cdot+\mathrm{O}_{2} \stackrel{\mathrm{k}_{2}}{\rightarrow} \mathrm{ROO}$.

$\mathrm{ROO} .+\mathrm{RH} \stackrel{\mathrm{k}_{3}}{\rightarrow} \mathrm{ROOH}+\mathrm{R}$.

2ROO. $\stackrel{\mathrm{k}_{e}}{\rightarrow}$ Unknown Products

Inhibitor $+\mathrm{nRO}_{2} \longrightarrow$ Products

以上の機錐は (1) 酸化速度が酸素分圧に 無関保なこ と（2）速度が initiator の濃度の1/2無に比例すること， （3）速度かＲHの 1 渠に比例することをよく説明する。 またInがラジカルであれば， $n=1$ である。またInと ROO・がかなり安定なラジカルをつくるならら゙， $\mathfrak{n}=1$ である，第 3 にはInが 2 個の ROO・と反応して安定な 生成物をあたえるならば n=2である.

第 4 には，第 3 と同様に 2 個の ROO. と作用し，そ の生成物がると酸化防止洞を不活性な化合物に変化さ せる場合は一般に $\mathrm{n}=1$ である。第 5 には上述の各場合 について生成物自身が酸化防止郕である場合は $\mathrm{n}$ は大き な值となる。

nを決めるためには 2つの方法がある，第1は initiation の速度をはっきりさせておいて既知濃度の酸化 防止剂の寿命から停止される連鎖の数を求める万法であ る. (4d3式参照).

第 2 性生成物の分析から見当つける方法である，これ には定量的な分析が必要である。たとえば，この方法で はつぎの二つの化合物では $\mathrm{n}=2$ である.すなわち

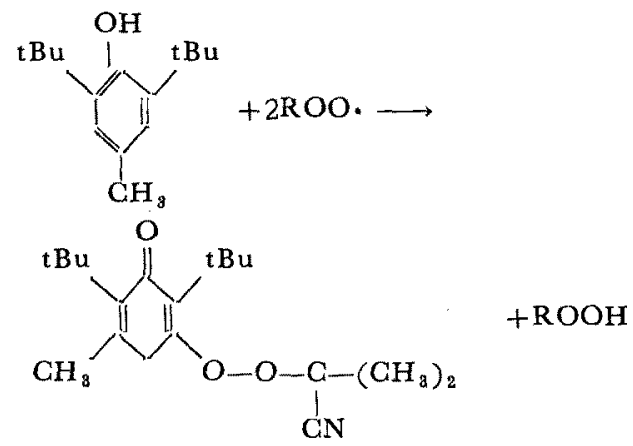<smiles>CO[14C](=O)C(=O)O</smiles>

一般に酸化曲楾は第 7 図の上うになるから，この非湖制 の部分を外插して酸化防止郕の寿命が求められる。

酸化防止剂の寿命は同一の酸化防止剤では濃度に比

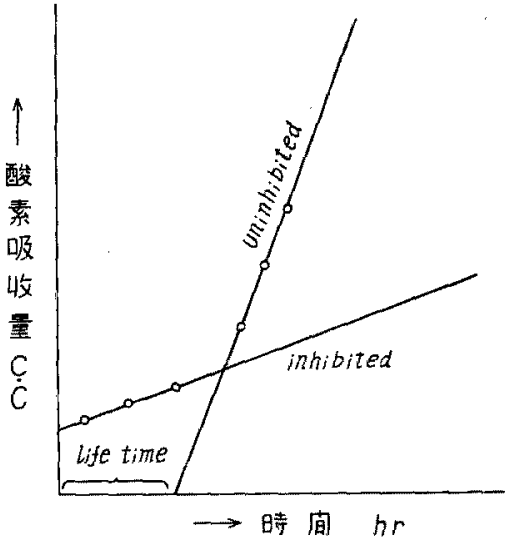

第 7 図

例している. initiator として用いる AIBN の分解速 度，すなわち initiation の速度はよくわかっているか ら,この上うにして求めた $\mathrm{n} の$ 值第12表に示す.

第 12 表 クメンのクロロベンゼン溶液の inhibited oxydation $62.5^{\circ} \mathrm{C} 1$ atm $\mathrm{O}_{2}$

\begin{tabular}{lc}
\hline \multicolumn{1}{c}{ 酸化防止剂 } & $\mathrm{n}$ \\
Chloranil \& Sym-Trinitro benzene & 作用广L \\
2,6 di t-butyl p-cresol & 2.0 \\
2,5 di t-butyl hydroquinone & 0.85 \\
Diphenylpicryl hydrazyl & 1.98 \\
4 t-butylcatechol & 2.00 \\
N Methyl aniline & 2.0 \\
p-Methoxy diphenyl amine & 3.3 \\
Diphenyl picryl hydrazine & 2.6 \\
Tetraphenyl pyrole & 1.6 \\
B-Naphthol & 2.1 \\
diphenyl amine & 2.8 \\
NN' Diphenyl-p-phenylene diamine & 2.2 \\
pp' Dihydroxy azobenzene & 2.0 \\
p-hydroxydiphenyl amine & 2.1 \\
2,2 Bis(4-hydroxyphenyl)-propane & 4.1 \\
p-cresol & 2.2 \\
o-cresol & 2.2 \\
phenol & 2.0 \\
\hline
\end{tabular}

この表に执いて, diphenyl amine と p-Methoxy diphenyl amine ではn は整数ではないが,これは diphnyl amine らの初めの生成物がれれ自身酸化防止 剤であるからと思われる。 また 2,5 di-t-butyl hydroquinone の場合には初めに生成するセミキノン基が二 分子重合すると思われる.

以上で酸化防止剂とその扣制能力の化学量諭的な関係 が明らかとなった、つきに先に述べたようにアミン系の 酸化防止剂に同位元菜效果のないことを彼らは実験した が，その事寒をもとにしてつぎの上うな水素のあずかる 段階か律速段階でないとをを想像した。 
$\mathrm{Ar}-\mathrm{NH}-\mathrm{Ar}+\mathrm{RO}_{2} \longrightarrow \mathrm{ArNi}+\mathrm{ROOH}(4 \mathrm{~d} 14)$

特別の形のものとして, dihydrophenazine,

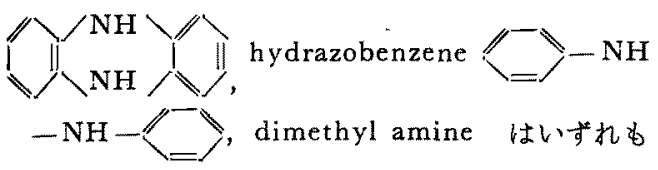

N-Methyl aniline より酸化防止作用が弱く，これに 反して容易に酸化される， $\mathrm{NN}^{\prime}$ diphenyl $p$ phenylene diamine は非常に強い酸化防止剤でこれは水素のやり とりが問題であるように思われる.これら diamine 系 北合物は Hammett の法則からもはずれていて，フェ ノ一ルやアミンとは異なる機棈によるすのと思われる.

つぎに置換基の影響については，一般には既に述ぺた ようにHammett の法則が成立している。このさい酸化 防止の能率はつぎのように測定した。

Initiation $の$ 速度=termination $の$ 速宜

$$
2 \mathrm{ak}_{i}[\mathrm{I}]=2 \mathrm{k}_{\text {In }}\left[\mathrm{RO}_{2} \cdot\right]^{2}[\mathrm{In}]
$$

$こ こ に \quad a=$ initiation $の$ 効率

$\mathrm{k}_{i}=$ initiator $の$ 分解速度恒数

$[I]=$ initiator $の$ 濃度

$\mathrm{k}_{\text {In }}=$ 速度恒数でこれは速度恒数と平衡恒数 の積でできているように思われる。

[In]=酸化防上剂の濃度

$$
\begin{gathered}
\gamma=\frac{-\mathrm{dO}_{2}}{\mathrm{dt}}-2 \mathrm{ak}_{i}[\mathrm{I}]= \\
\mathrm{k}_{\mathrm{g}}[\mathrm{RH}]\left\{\frac{\mathrm{ak_{i }}[\mathrm{I}]}{\mathrm{k}_{\ln }[\mathrm{In}]}\right\}^{\frac{1}{2}}
\end{gathered}
$$

ここに2 $2 \mathrm{ak}_{i}[\mathrm{I}]=$ initiator による酸素の吸収速度と なる.

この式は先の (4d3)が $\mathrm{n}=1$ としたのに対し, $\mathrm{n}=2$

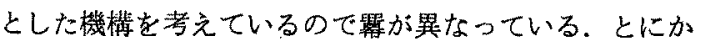
$\left\langle\mathrm{k}_{8} / \mathrm{k}_{I n^{\frac{1}{2}}}\right.$ は吸収速度に比例するから，これの逆数で酸 化防止能力を表わしたすのが，第6図の此効率である. そうしてフェノールが基準として 1 にとってある。

つきに酸化防止揱の効率は，各溶媒中で行ならとその 逞電恒数によって影響をうけることを認めた。テトラリ ンの $62.5^{\circ} \mathrm{C}$ に扔ける酸化を N-Methyl aniline て inhibit した場合の酸化防止の効率と溶媒の関係を第 13 表に示す。

\begin{tabular}{lcr}
\multicolumn{3}{c}{ 第 13 表 } \\
\hline 溶 & $\mathrm{k}_{8} / \mathrm{k}_{\mathrm{I}^{\frac{3}{2}} \times 10^{4}}$ & $\begin{array}{c}\text { Dielectric } \\
\text { const. }\end{array}$ \\
\hline Benzene & 4.8 & 2.27 \\
o-dichlorobenzene & 6.0 & 10.36 \\
Chlorobenzene & 5.27 & 5.62 \\
Nitrobenzene & 5.15 & 34.82 \\
Nitromethane & 1.92 & 35.86 \\
CGl $_{4}$ & 0.63 & 2.23 \\
\hline
\end{tabular}

また容易にとれる水菜のないNN, $N^{\prime} N^{\prime}$ tetra methyl p-phenylene diamine はよい酸化防止剂であるが，そ の, $\mathrm{n}=$ [stoichiometric factor $]=1.75 \sim 1.90$ でって このものは二個の連鎖を切断する。

ニトロタタン中で実験すると紫色加認められる.フ口 ロベンゼン中ではこのようなことはないが，これにニト ロメタンを加えると紫色加生じる．安た水を加えると水 層が紫色になる、これは Wurster cation で，クロロ ベンゼン中にある中間体が水で分解して Wurster ca${ }_{\operatorname{tion}}^{\mathrm{Me}} \mathrm{Me} / \mathrm{N}-Z-\mathrm{N} / \mathrm{Me}$ になるものと思われる.

この上うな事実から，(4d13）の反応の内容が水素引 き抜き反応であって，こ机が律速的と考えるのは困難で

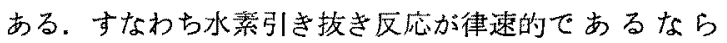
ば，酸化防止剂の作用に同位元紫効果があるは市 る.しかしアミンの場合には同位元素效果は認められな い. 第 $2 に$ tetra methyl $p$-phenylene diamine およ び dimethyl anilineのように動きやすい水素を有しな いむのもよい酸化防止剂でること，また逆に hydraー zobenzene や dihydrophenazine の上うに脱水素すれ ば安定なラジカルとなると思われるものがあまり効果の ないこと，またパラ位にニトロ置換したメチルアニリン

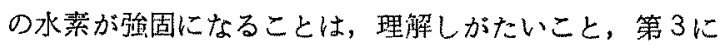
置換基についてはHammett の法則が成立していてその $\rho$ が大であることから核また恃性基への電子の授受が 大きな役割りをしていること，第 4 に酸素吸取速度が (4d15) 式のように initiator の濃变の1/2乘に比例してい るのは，反応はROO.について 2 次であることであっ て，これは，脱水菜反心 (4d14)は可逆的であってつぎ のもう一分子との反応が律速的であるということで，こ れは考えにくい，また一方三置換つェノールはROO.と 反応して cyclohexadienoneを生じる.これらのことか らフェノールの場合には第一段階を水素引き抜きとしな いように機㹃を考えた。<smiles>OC1=CC=CC[IH]1</smiles><smiles>[R]OC1(C)C=CC(O)=[Y]1C([R20])[O-]</smiles><smiles>[R]OC1(C)C=CC(O)C=C1[R20]</smiles>

しかしながらこの考え方には異諭があって，第1には

( 83$)$ 
tーbutyl 基などはこの反応の立体障害となると思われる が，実際には $\mathrm{t}$-butyl 基の置換は防止能を強くしてい る、第 2 にはオルトとバラ置换体は同じょうな作用をす っているが，これは (4d17)の前段階(4d16)ですでにこ の位置に結合が生じている㫴とは相容れないものてあ 马.

以上のようなことを説明するためには，ROO・と酸 化防止剂との結合というものは弱いるのでadduct とい らよりは loose complex と考光方がよい.すなわち （4d16）に示すような強い結合ではないと考えられてい る.そうしてこの complex の安定度は $\pi$ 電子密婆によ るものである159).これで Hammett の法則が成立して いることが説明される.

それてこの機構は次式で表わされる.

$$
\begin{aligned}
& \mathrm{RO}_{2} \cdot+\mathrm{In} \approx\left[\mathrm{RO}_{2} \cdot \rightarrow \mathrm{In}\right] \\
& {\left[\mathrm{RO}_{2} \cdot \rightarrow \mathrm{In}\right]+\mathrm{RO}_{2} \cdot \stackrel{\mathrm{k}_{\mathrm{In}}{ }^{\prime}}{\rightarrow} \text { product }}
\end{aligned}
$$

さて先の termination と initiation が等しいとおい た式の $\mathrm{k}_{\mathrm{In}}$ 恃前述のよろに $\mathrm{Kc} \times \mathrm{k}_{\mathbf{1 n}^{\prime}}{ }^{\prime}$ で表わされ得る が，(4d19）の反応は相当速いので Kck多く支配され ると思われる.そうして多くの場合拡散律速となる.

これがアミンに同位元素効果の認められなかった理由 とも考克られている. 一方(4d19)の反応は ROO. の結 合がゆるいので化合物によって種々の反心経路通る。 もしも2 個の水素が利用し得るならば, alkoxy radical は，2 個とも hpoになる。むしも1個の水菜しか利用 されないならば，残部はdienone や dienamineに変化 する.

利用できるラジカルが，1個もない時は，他のラシカル とcomplex の反応は抢そくなり，complex の安定度た けで酸化防止剤の能力を表わせなくなる diethylaniline と tetramethyl p-phenylenediamine はラジカルと 反応して complex をつくり，これがまた他のラシカル と反応してつきのような生成物となると落点られる。

しかし aryl peroxide は非常に不安定で得られない 点に問題がある。

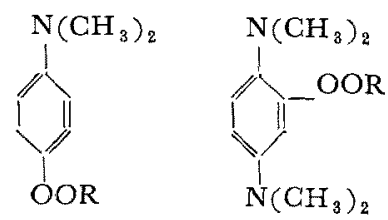

また笲に述べたように， tetra methyl p-phenylene diamine の場合に中間体を加水分解すると Wurster cation老あた劣ることから，つぎのように考えられる。
$[\mathrm{ROO} \cdot \rightarrow \mathrm{In}]+\mathrm{H}_{2} \mathrm{O} \longrightarrow \mathrm{ROOH}+\mathrm{In}^{+}+\mathrm{OH}^{-}$

また酸化防止郕の能力と溶媒の透電洹数の間にははっ きりした関係がなかったがここれは complexの棈造に $\left(\mathrm{RO}_{2}-\mathrm{In}\right.$ ・) の上うな有極性の棈造の寄与が小さいため と思执る。

以上が Hammond らの見解であるが, Pederson ${ }^{1499}$ るまた同位元等效果のないことから水索のやりとりが酸 化防此機棈の本質ではないと考えている，以下彼の考え についてのぺる.

Hydroperoxy radical が次式によってhpoになった としても，窒素を含むラジカルが生成するのて，反灾連 鎖は停止しない.

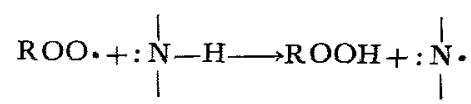

それでアミノ基から電子をとって peroxy anionにな る.すなわら

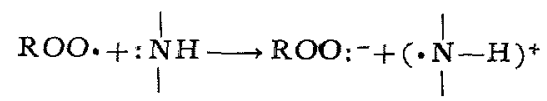

もしもこの反応が不可逆ならば，アミンから脱水絜する ことなしにtermination が抗こる，生成した ROO: 一 つぎにプロトンと反応して hpoになるかまたはROO. になるか仕不明である。

フェノールの場合も同様に，いずれも ROO. te rmination に含んでいたが，つぎに示す化合物では他 のラシカルによる termination か酸化防止剂の機構て あるという可能性を示している。

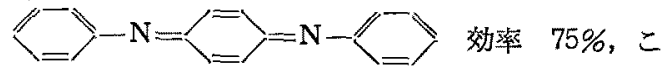
の化合物は ROO.にあたえられる水桬がない，また電 子をあたえる可能栍もない。<smiles></smiles>
これは炭化水素 のラシカルと直 接反応する、酸 化防止効率は87\%である。

彼は結諭として酸化防止剂の機棈にはつぎのうに2 種あるとしている.これは Hammond, Boozer の考え を更に精密にしたものということができよう。

(1) 電子を ROO・にあたえる.

（2）水素を ROO.にあた方.

（3）少し酸化されてから ROO.と結合する.

（4）ROO.を含まない他の機棈.

以上のように，inhibitor の作用機棈には各種の6の があるのでこれら2種を湿合すれば，おのおの機構上 の作用点が異なり相乗作用が期待できるが，2種湿合の 
場合は第 14 表に示すように117) inhibitor 同志ては相加 作用となり， inhibitor と peroxide decomposer で は相采作用となる.

をた PBNA 2\%,MB 2\%，执よひ PBNA 1\%+M B 1\%を含む加硫ゴムでについては，老化時の応力綏和 の研究からPBNA と MBの併用の場合のモシュラスの 変化について拷察すると相乗作用加諗められる ${ }^{181}$.

Walling ${ }^{151)}$ のフェノールと過酸化物の反心の研究に ついては先にも触れたが, 彼らはつぎのような実験事実 をもとにしてフェノールが過酸化物によって酸化される 機構を推諭している.これは酸化防止剤の作用機棈の点 から見ても，酸化防止剂としてのフェノ一ルは過酸化物 と作用する可能性るあるのでその段階を研究したものと して興味あるすのである.

この反応速度は次式にしたがう二次反応である. $-\frac{d \text { (peroxide) }}{d t}=k_{2}$ (peroxide) (phenol)
また先にのへたように水酸基の水装を重水菜で置換す ると同位元菜効果がある. ベンゼン中でメタクレゾール と Benzoyl peroxide との反応の活性化熱 $\Delta \mathrm{H}^{+}$は17 $\mathrm{kcal} / \mathrm{mol} \tau$, 活性化エントロピー $\Delta^{+}$は $-26.7 \mathrm{cal} /$ degであった。

反心速度には溶媒効果が見られてその順序はつぎの上 らである. ニトロベンゼン>ベンゼン>アルコール>カ ルボニール化合物，すなわち水素結合の強い溶媒では速 度は小さい，また酸，塩基触媒反応ではない。

この反心に radical trap として重合性そノマー，沃 度，酸素索加えても影響がない。

フェノールに電子供給基罝換すると速度がますが， 簡篗な Hammett の法則は成立しない.

反応は水酸基への立体障害の影響をうける，むた過酸 化物の種類が変ると速度が変るが，これは熱分解とは平 行関係にない，反応中に $\mathrm{CO}_{2}$ の発生がない.

以上の事実からラシカル的な反応でないかをなはHa-

第14表 鉱油 $9155^{\circ} \mathrm{C}$ の安定化

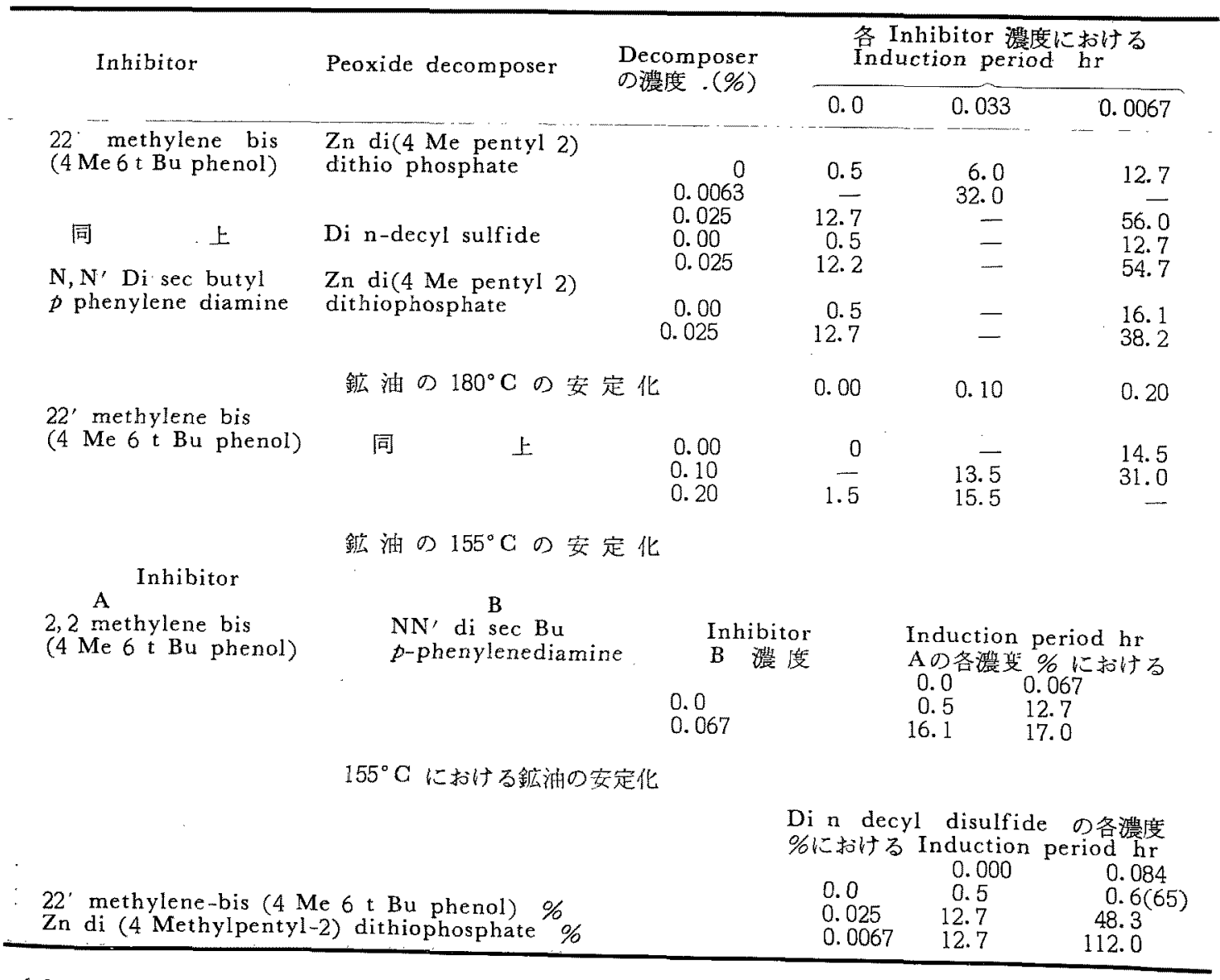


mmond の上うなラシカルと酸化防止剂の中間体の生成 が考えられるが，中間体の確証がないから非ラシカル的 な反応と教える方がよいとしている．この反応の経路に ついてすでに本節において生成する酸化生成体につい てのところでのべたところであるが，このような経路は 大きな鱼の活性化エントロピーと一致するものであ る.

このよ5に非ラシカル的な機構が考えられる一う，フ

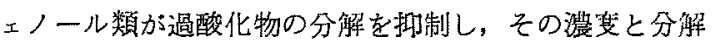
速度の関係には極小があることは，何か誘発反応をフェ ノールがつふしているのではないかと洘えられている.

また Bickel140)らす先にのべたようにフェノールと 過酸化物の反応を行なっている. 酸化防止剂としてのフ ェノールはつきの二つの点で特垷づけられる（1）酸化 防止剂の效察すなわち ROO. がフェノールまたは炭化 水紊から水菜引き抜きをやる速さの比，(2) Chaintransfer reaction $\mathrm{A} \cdot+\mathrm{RH} \longrightarrow \mathrm{AH}+\mathrm{R}$. の速度である. 一般にフェノールは炭化水素より速かに反応する。 また （2）の反心速度はオルト位の犆換基の大きさを堌加する と減少する. 2 つの o-tert butyl 基は完全にこの反応 を停止してしをう。また動力学的研究によると 3 つ型 があってそれはおのおの別の機構に属している.すなわ b,

(a) 反心速度は $(\mathrm{RH}) /(\mathrm{AH})$ に比例する。ここに $\mathrm{RH}$ は崖化水媇で， $\mathrm{AH}$ 酸化防止剂である。

a1) $R_{2} \longrightarrow 2 R$.

$\mathrm{R} \cdot+\mathrm{O}_{2} \longrightarrow \mathrm{ROO}$.

$\mathrm{ROO}+\mathrm{RH} \stackrel{\mathrm{k}_{r}}{\rightarrow} \mathrm{ROOH}+\mathrm{R}$.

$\mathrm{ROO}+\mathrm{AH} \stackrel{\mathbf{k}_{b}}{\longrightarrow} \mathrm{ROOH}+\mathrm{A}$.

2A. $\quad \stackrel{\mathbf{k}_{d}}{\longrightarrow} \mathrm{A}_{2}$-termination

ここに応生成物の検討か, $5, A==$

である.すなわらベンジル型の二量体化で termination が打こる.

a2) $\mathrm{ROO}+\mathrm{AH} \stackrel{\mathbf{k}_{a}}{\rightarrow} \mathrm{ROOH}+\mathrm{A}$.

$$
\begin{aligned}
\mathrm{ROO}++\mathrm{A} \cdot \stackrel{\mathrm{k}_{t}}{\rightarrow} \mathrm{ROOA} \text { (stable) } \\
\\
- \text { termination }
\end{aligned}
$$

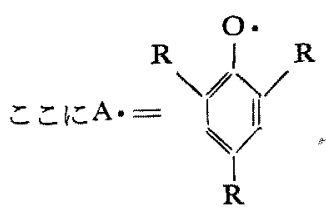

$\mathbf{k}_{a}$ と $\mathbf{k}_{b}$ はの型が異なる

a3）(a2）と（a3）が湿合して执こる。

(b) 酸化防止剂の濃宽により酸化速度に最小の表わ れるものでは，つぎの二反応の結合として動力学的な説 明ができる。
$\mathrm{A} \cdot+\mathrm{RH} \longrightarrow \mathrm{AH}+\mathrm{R}$.
chaintransfer
A. + ROO. $\longrightarrow$ ROOH(stable) termination

(c) 酸化速度加 [RH] と $1 /$ (antioxydant) とに 比例する場合はつぎの二反応をもとにして生成物と動力 学を説明した。

$$
\begin{array}{ll}
\mathrm{A} \cdot+\mathrm{RH} \stackrel{\mathrm{k}}{\mathrm{k}} \rightarrow & \text { chaintransfer } \\
\mathrm{A} \cdot+\mathrm{A} \cdot \longrightarrow \mathrm{A}_{2} & \text { termination by dimerisation }
\end{array}
$$

さらにアルキルフェノールの構造と反応性については 第一段階は ROO.によるフェノールの OH からの水 羍の奪取であろうと考えて，オルト位に置換があると障 害によってROO．の反応を阻止するが，才ルト䈯換は $\mathrm{OH}$ と核の共平面棈造を破壞するので $\mathrm{O}-\mathrm{H}$ 結合が弱ま る.このため水素がとられやすくなるのて，この相文す る2つの効果のため個々の場合場合によって考点対ばな らない.

また強い立体障害のあるフェノールには，chain transfer はおこらない：これはその阻止作用と $\mathrm{O}-\mathrm{H}$ が弱くなるためである.オルト位の置換基が同じならば その chain transfer は同程度である。

p-methyl と p-tert butyl を比較すると, p-tert butyl のときは chain transfer は少ないが, p-methyl のときは相当おこる.これは $p$-methyl が攻整される ためである.この chain transfer がないことが ROO. をつぶすのて酸化防止剂として有効である.

\begin{tabular}{|c|c|c|c|c|c|}
\hline \multicolumn{4}{|c|}{$\begin{array}{l}\text { アルキルフェノ樭 } \\
\text { ル中のアルキル基 }\end{array}$} & 酸化防正 & $\begin{array}{l}\text { chain } \\
\text { transfer }\end{array}$ \\
\hline & $\begin{array}{l}\text { tBu } \\
t B u \\
\text { tBu } \\
\text { tBu } \\
\mathrm{Me} \\
\mathrm{Me} \\
\overline{t B u}\end{array}$ & $\begin{array}{l}\mathrm{tBu} \\
\mathrm{Me} \\
\mathrm{tBu} \\
\mathrm{Me} \\
\mathrm{tBu} \\
\mathrm{Me} \\
\text { tBu } \\
\mathrm{Me}\end{array}$ & $\begin{array}{l}t \mathrm{tBu} \\
\mathrm{tBu} \\
\mathrm{Me} \\
\mathrm{Me} \\
\mathrm{Me} \\
\mathrm{Me} \\
- \\
-\end{array}$ & $\begin{array}{c}32.0 \times \\
33.5 \times \\
? \times x \\
250 \dagger \\
16-31 \times \\
260-350 \dagger \\
86-100 x \\
118+\end{array}$ & $\begin{array}{l}0 \\
0 \\
\text { 大 } \\
0 \\
\text { 小 } \\
0.0035 \ddagger \\
0.0086 \pm \\
0\end{array}$ \\
\hline
\end{tabular}

第15表に酸北防止斉の効力と chain transfer の関係 老示す。

第 15 表 
表中酸化防止効力は， $\times 2 \mathrm{k}_{a} / \mathrm{k}_{r} ，+\left(2 \mathrm{k}_{a}+\mathrm{k}_{b}\right) / \mathrm{k}_{r}$ て表 わしてある. 要するに ROO.が酸化防止用と反応する 速度と宸化水素と反応する速度との比である。

chaintransfer は $\mathrm{k}_{c}$ で表わせるが，十は $\mathrm{k}_{c} / \mathrm{k}_{d^{\frac{1}{2}}}$ で dimerisation によるA.の termination $と$ chaintransfer の速度の此として考えている.

以上は酸化防止剂について化学反心をむとにして考 えてきたが，この他溶解度その他の物理的な問題があ り，中でも拡散は，発生してくるラシカルを捉えるため の第一段階としてとくに重要である.

これに関しては Kuzminskii160) らが研究している. SBRに $1 \%$ PBNA を混合し，その酸化による消費速度 を $100^{\circ} \mathrm{C}, 120^{\circ} \mathrm{C}$ において求め，つぎにこれとモシュ ラスの変化との関係を求め, 化学変化と機械的性質との 閶係圭明らかにした，酸化防止剤の消失の速度と醉化の 中心となる活性中心の生成の速度とが酸化防止剛の結合 速度と等しいとおくと, 反応初期にはモジラスの隇少 があり最後に增加があるということが説明される.

ゴム中では液体の場合よりゴム中の拡散が問題である か，PBNAについて应散恒数を求見ると， poly

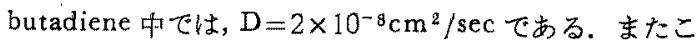
の活性化エネルギーは $12.5 \mathrm{kcal} / \mathrm{mol}$ でる. 拡散恒数 はゴムの種類によっても異なっていて butadieneacrylronitrile 共重体 WSKN-26 においては polybutadiene の $1 / 6 \sim 1 / 5$ であり， polyisobutyleneに おいてはWSKN-26 よりなお低い值である。

酸化防止郕の程類によってももち諭舅なる訳である が, polybutadiene 中においてはつぎの順であった。

$\mathrm{PBNA}>$ diphenylamine $>\mathrm{S}>$ dinaphthyl-p-phenylene diamine.

上記の中でもっとも搪散恒数の大である polybutadiene中に拈けるPBNA の場合 $\left(2 \times 10^{-8} \mathrm{~cm}^{2} / \mathrm{sec}\right) に$ 抋いても，酸素の搪散恒数は $1.5 \times 10^{-6} \mathrm{~cm}^{2} / \mathrm{sec}$ であ って，これがゴム中では液体中上り酸化防止削の活性が 小さい原因と考えられている。これに反して液体中では 酸化防止剂と酸素の拡散恒数法大体等しい。

\section{5. 実際的な分野における酸化防止剂}

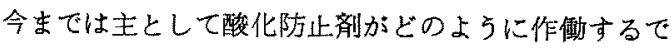
あららかということに関係してのへてきたが，つぎに実 際的な問題に使用した場合を酸化防止剂という立場から 眺めて見る。これに関しては実に多種多様の研究があっ て，そのすへてを紹介するのは困難であるのでその中の 主な点について記して見ることにする。
石油方面に用いられている酸化防止剂にはつぎのよう なあのがある゙61)。

Camyl oleate と硫黄との反応生成物である硫化エス テル.

$$
\underset{\mathrm{Me}-\left(\mathrm{CH}_{2}\right)_{2}-\underset{\mathrm{C}}{\mathrm{C}}-\mathrm{O}-\left(\mathrm{CH}_{2}\right)_{m}-\mathrm{Me}}{\mathrm{H}}-\left(\mathrm{CH}_{2}\right)_{n}-\stackrel{\mathrm{O}}{\mathrm{C}}
$$

硫化テルペン.<smiles>CC1CCC(C)C(C2CC2)C1S</smiles>

オレフィンと硫黄との反応生成物.<smiles>[R]C1SC(C)C([R])SC1C</smiles>

ジルファイト. $\mathrm{ArCH}_{2}-\mathrm{S}-\mathrm{S}-\mathrm{CH}_{2} \mathrm{Ar}$ など. および tert alkyl phenol と SCl などの反心生成物.<smiles>[R]C1CC(SSSC2CC([R])C([R])C(O)C2)CC(O)C1[R]</smiles>

またこの水酸基をエステルにしたものまたは Ni 塩に したもの.

Dithiophosphate 類.

Thiophosphoric acid amide.<smiles>[R2]NP(=S)(N[R2])SP([NH2+])(=S)SP(=S)=S</smiles>

phenothiazine は高温に打ける渭滑油などにはよい酸 化防止倣である。アミンやフェノ一ルは低温ではよいが フランクケース油のよラに高温にさらされるものには向 かない1622.

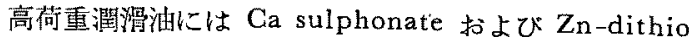
phosphateまたはテルペンと $\mathrm{P}_{2} \mathrm{~S}_{5}$ の反応生成物がよい といわれている.

ガソリンに各種のフェノールを加えてその酸化防止能 を調べて見ると，それは使用するガソリンによって異な っている161-b)、生潤滑油にはセレンの化合物む用い られる。 
カーボンブラックは酸化防此作用があるが，一度酸化 してゴム質を生じた油に加えてす効果はない168)。

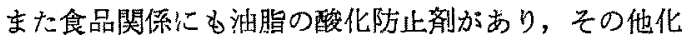
㛇品などに山用いられている、食品関係にはつぎのよう な政造のすのがある。

tert-butyl hydroxy anisole てここれは二つの異性 体があるが，A型の力がB型より有効であるとされてい る。<smiles>COc1ccc(OC)c(CC(C)(C)C)c1</smiles>

$n$-dihydroxy guaiaretic acid (NDGA)<smiles>Oc1ccc(CC=CCCc2ccc(O)c(O)c2)cc1O</smiles>

$\alpha$-tocophelol<smiles>Cc1c(C)c2c(c(C)c1O)CCC(C)O2</smiles>

などがある、

ゴムに関するものについては多くの綜説文献 ${ }^{184) か ゙ あ ~}$ る.ゴムにおいては酸化による劣化は引張強さの低下と いう上うな現象となって表加るから，酸化防止の目的 は实際に生じる有害な影響を除去することである。これ には酸菜吸収と忍力緩和主測定する方法などが少化の上 い検討法であろう。

普通は，加玨酸素法とかギヤ一法とか，酸素吸双法な どがある、ギヤ一法では真の老化はきめられないので， 加圧酸素法の定常部の速度加見当をつけるのがよいと いわれる。

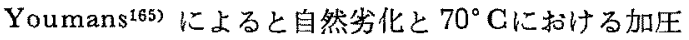
酸素法, air oven 法ならびに air bomb 法との相関関 係はつきの上うであって，引張強さ，伸び，モジニス などがどう対応しているかが知られる。 今引張強さの対 応を見る。

他のものについても打括むね同様の結果が得られる.

またアセトン抽出ゴムをべンゼンなどにとかし，これ に酸化防止剂を加皃て数日間の粘度の变化から效果を判 定する方法もある(16).

E. N. Novikoza ${ }^{167)}$ キシレン溶液中のゴム老北に対 する酸化防此绪の効果を研究しつぎ順位を得ている。 これは系中に鉄を微量混合したときの成續でる。
第 16 表

\begin{tabular}{|c|c|c|c|}
\hline 自然老化年 & 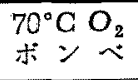 & air oven & air bomb \\
\hline & 日 & 日 & 分 \\
\hline 1 & 0.17 & 0.5 & 5 \\
\hline 2 & 0.41 & 1.25 & 13 \\
\hline 3 & 0.75 & 1.75 & 18 \\
\hline 4 & 1.13 & 2.50 & 25 \\
\hline 5 & 1.5 & 3.50 & 32 \\
\hline 14 & 6.0 & $21^{+}$ & 97 \\
\hline 15 & - & - & 105 \\
\hline 18 & - & - & 143 \\
\hline 21 & 一 & - & 173 \\
\hline
\end{tabular}

1 naphtol $>$ aldol $\alpha$ naphthylamine $>2$ naphthol $>$ PBNA $>1$ naphthylamine $>2$ naphthyl amine $>$ naphthaline $>1$ nitroso naphtol.

アルキルフェノールなどを SBR 扎よびブナ N に用 いた Kitchen ${ }^{1689}$ らの結果によれば，ブナ $\mathrm{N}$ に対して もっともよいのは, 2,4 dimethyl 6 isobornyl phenol, 2,6 di tert-butyl 4 methyl phenol, 2.6 dioctyl phenol である。

SBR とその加硫物に対する酸菜の吸取では DBPCか; よく, triphenyl phosphite はむしろ酸化を侹進する.

また alkoxy 基のあるフェノールについてむ研究され ているが，その中最良のものは 4 benzoyl oxyphenolな らびに 4 methoxy 2,6 di tert-butyl phenol てある.

この 4 benzoyl oxyphenol は例外であるが，一般 的にはオルト位に1個または 2 個の置換のあるるのが有 効な酸化防止珮である。

アルキルフェノールに拈けるパラ位のハロゲンはパラ 位のアルキルと同様に有効であり，また methylene bis phenol 法きわめて有効でそのメチレン基を $\mathrm{S} に$ 変える ともっと強力になる ${ }^{169)}$ 。

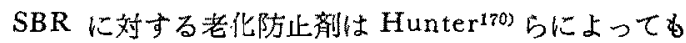
研筧されている. 従来は SBR にはPBNA や diphenylamine aceton 䌅合物 (BLE) が用いられていたがい ずれる活染性で，つぎに alkylated diphenylamineが 用いられ活染性は改善されたが效果がよくなかったとい うことである.それで非污染性のものについて研究され

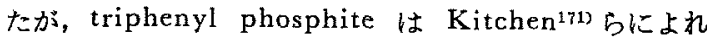
ばあまりよくないので彼らはつぎののについて研究し た結果, higher alkylated aryl phosphite が最良であ るとした. 彼らの研究したるのはつぎのものである.

BLE, heptylated diphenylamine, cresol sulfide, styrenated phenol, alkylated aryl phosphite. また 
Taft らは ${ }^{172)}$, PBNA; BLE; stalite (mixed mono\& diheptylated diphenylamine); Polygard (tris nonyl phenyl phosphite); Wing Stay $\mathrm{S}$ (substituted alkylated phenol); $\beta$-conidendol; 2246(22'methylene bis 4 methyl 6 tert-butyl phenol) を SBR の酸化 防止に用いたさいの dilute solution viscosity;moony viscosity; 引張強さ, constant loading elongation modulus;について研究した，彼らが示すように，酸化 防止剤はゴムの物理的性質に影響をあた常をるが，加硫系 の相異によってもまた酸化防止剂の効果が暴なってく る，これは石油の場合にも基泊によって酸化防止の効果 が異なることと類似している，例えば $\mathrm{Zn} \mathrm{mercapto-}$ benzimidazol はM妾用いて加硫したものには效果があ るが，Dを促進戍としたものには効果がない：これに反 $\downarrow \tau$, bis (2-hydroxy-3 tert butyl 5 methyl phenol) methane はDのときは効果があるが，Mのときは効果 が少ない．また相乗作用についても加硫系で異なってい

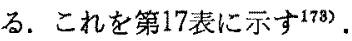

\section{第 17 表}

\begin{tabular}{|c|c|c|}
\hline \multicolumn{3}{|c|}{ 加酼系による酸化防止㨈の差 } \\
\hline 酸化防止剈 & M 加 硫 & $\mathrm{D}$ 加 硫 \\
\hline PBNA & Good & Fair \\
\hline 2246 & Fair & Good \\
\hline $\mathrm{Zn} \mathrm{MBI}$ & Very good & Slight \\
\hline $\begin{array}{l}2246+\mathrm{Zn} \mathrm{MBI} \\
\text { Synergetic }\end{array}$ & Yes & No \\
\hline
\end{tabular}

SBR の酸素吸収量と物理性の関係を Shelton む研 究している174)。それによるとカーボン配合物について はPBNA を老化防止郕として，用いると $1.25 \%$ 添加し たとさに酸絷吸収速度が最小となり，これ以上でるこれ 以下でも速度は大となる。これは天然ゴムですほほ同様 である. 天然コムにハイドロキノンや2,6 di tert-butyl p-cresol を加えたときる同㥆の傾问がある.引張強さ や伸びも同じように変化して吸収速度の最小のときがー 番よい老化性を示す。しかし SBR の無色物で酸蓄の 吸收と劣化とは必ずしも一致していない。

また NN' di sec-butyl p-phenylenediamine をl, $2,3 \%$ 各添加したるのでは，酸秦吸取速度は無添加のも のとそれぞれあまり変化はないが，モジュラスや引張倠 さは非常に改善され，この場合は添加量を增加する汪ど 老化性がよい：この場合は吸収された酸素が無害になる ので Le Bras の “deactivator”と関係のあるむのであ $る^{(775)}$. 引張強さの変化からはPBNA が一番よい酸化防 止郕で,つきが $N^{\prime} N^{\prime}$ di sec-butyl $p$-phenylene dia-

(89) mineである.フェノ一ル類は劣っていて，2,6 di tertbutyl pcresol はハイトロキノンより多少よい程度であ る. 酸䅇吸収の成績のみから此較すると PBNA と ditert butyl p-cresol は同じようである。そうしてNN' di sec-butyl $p$-phenylene diamine は無洒值のよう に見える．すなわち酸素吸収量のみで効果を判定するの は危険であるまた過剩の酸化防止到はSBR を堅くし， 天然ゴムを柔らかくする結果を得ている，これはゴムの 椿造の相異として説明されるべきすのと考えている.

カーボンブラックも酸化に影響がある副。これについ ては前にもふれたが，これは未加硫の cold rubber や 天然コムの裳の酸化を防止する.それは未加硫のコムの ゲル化を進めるためである。

カーボンブラックは自働酸化の自己接触的な段階の前 段である定速の部分の速度に影響する，その部分の速度 が増加する、これに反して自己接触的な部分の速度は抑 制される．それは反応連鎖の carrier となる中間酸化物 がカーボンブラック上に強く吸左されて除去されるため であると洘えられている189)。また化学吸着した酸萦自 身が酸化防止作用を有しているようにも考えられている ${ }^{16)}$.またShelton ${ }^{41)}$ は $N$-cyclohexyl benzthiazyl sulfenamide て加硫したゴんについて，アミン系の老化防 止剤を用いた場合の自働酸化の定常速度の部分ては，速 度 $\mathrm{v}=\mathrm{kPo} \mathrm{2}^{\text {z }}$ であって，これはBollandの機䇅と合わな いことをのべている. また PBNA (Santoflex B) 2,2, 4 trimethyl 6 phenyl 1,2 dihydroquinoline (Tenammene-2); $\mathrm{NN}^{\prime}$ di sec-butyl $p$-phenylene diamine; 2,6 di tert-butyl p-cresol(Deenas); Bis (3 tertbutyl 5 methyl 2 hydroxy phenyl) methane (2246 ); hydroquinoneについて定常速度を見ると，コム100 に対し1〜3添加しは場合に第18表のようである174).

表のように配合量と効果との関係には極大值があ り，また負号のわのはむしろ酸化を佣進しているのであ る.しかしこれについては，酸素の吸取速度のみで耐老 化性を考えてよいかとうかには閏題があり，とくに， Tenammeneなどで負数が著しいのはそれ自身が酸化さ れるためではないかと思われる点がある。

長期にわたる实験では，PBNAを加えたのでは 22 年 間にその全含有量が半分となった。 また伸びと引張強さ は2分の1になった。 $300 \%$ のシュラスは10年間は上 暴し後一定になった165》。

加硫の方法によっても酸化防止凧の効果に差が市るよ うで DDA，BLE は水蒸気加硫の場合に，Agerite Stalite は萟空気加硫の場合によいといわれている177。 
第18表 酸化防止剂の沮度とその効果

\begin{tabular}{|c|c|c|c|}
\hline 酸化防止烱 & 配 $\mathrm{PH} \mathrm{R}^{\text {含 }}$ & $\begin{array}{c}\text { 効 } \\
\text { 酸薪中 }\end{array}$ & $\begin{array}{c}\text { 舆 } \\
\text { 空気 中 }\end{array}$ \\
\hline \multirow[t]{3}{*}{ PBNA } & 1 & 66 & 45 \\
\hline & 2 & 93 & 95 \\
\hline & 3 & 65 & 28 \\
\hline \multirow[t]{3}{*}{ Santoflex } & 1 & 100 & 100 \\
\hline & 2 & 94 & 90 \\
\hline & 3 & 89 & 86 \\
\hline \multirow[t]{3}{*}{ Tenammene } & 1 & 27 & -35 \\
\hline & 2 & -2 & -38 \\
\hline & 3 & -27 & -75 \\
\hline \multirow[t]{3}{*}{ Hydroquinone } & 1 & 48 & 44 \\
\hline & 2 & 7 & 37 \\
\hline & 3 & -27 & -12 \\
\hline \multirow[t]{3}{*}{ Deenas } & 1 & 52 & 73 \\
\hline & 2 & 81 & 88 \\
\hline & 3 & 94 & 100 \\
\hline \multirow[t]{3}{*}{2246} & 1 & 20 & 18 \\
\hline & 2 & 32 & 21 \\
\hline & 3 & 33 & 21 \\
\hline
\end{tabular}

酸化防止剂の混合使用については二三述べたが，つぎ のようなあのがよいといわれている。

天然ゴムとペルブナンとの混合物に対して，涌熱性の 酸化防止剂としては，aldol- $\alpha$-naphthyl amine とMB の混合物，をたある場合にはMB と4010の混合物かよ いといわれる.

ピベリシンならびに $\mathrm{N}$-hexyl piperidine や $N^{\prime}$ dicarbethoxy piperidine のようなものは光香族アミ

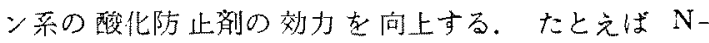
phenyl piperidine $\emptyset 33 \%$ t $\mathrm{NN}^{\prime}$ di sec-butyl $p$ phenylene diamine に添加するとinduction period

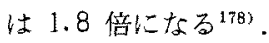

4 amino diphenyl amine $\longleftarrow 2$ aminodiphenyl amine または 2,4 diamino diphenyl amine を添加するとカ ソリンに対する溶解度が改瑟される、たたしこの場合蜼 位配合舅当りの效果は低下するようである ${ }^{179)}$ ，

この他酸化と考えられるすのにはオゾンによるるのが ある.これについては Biggs ${ }^{180 y} の$ 綜説がある。

オゾン劣化は二重絬合に関連しておこると考えられて いるがフィリッブ社の Hydropol で 29\% む二重結合 があるにかかわらすよい耐棵ソ性索示している。こ扎 に反してブチルは一般には酒才ソン性がよいがオソン劣 化をうける場合名すり，二霍絬合の念有量はHydropol
よりはるかに少ない.しかしこれについてはHydropol の二重結合の性算が诖うという説明と，このものの中に はワックスができているという説明とがある、ワックス は耐オソンン性を改善する。

多くの酸化防止戍は耐オソ゚ン性を改善しないことはす てにTuley ${ }^{81)}$ にり見出されている. antiozonant と して用いられているものは， $p$-phenylene diamine, ヘ ンチヂン, 44' diamino diphenylmethane, 1 ( $p$ aminophenyl) 2, 5 dimethyl pyrrole181) (これは時 が経つとブルームしてよくない) NBC(ワックスと併用 するとよくてこれはブルームによるものであろう). 酸 化防止戍の群の中で捜して得られたものが， 6 ethoxy 1,2 dihydro-2,2,4 trimethylquinolin である ${ }^{183)}$. そ れと同じころ $\mathrm{NN}^{\prime}$ dialkyl p-phenylenediamine が:各 所の研究所で有效であることが見つけられた18ま。これ よりは NN' di sec-butyl benzidine が種々の点でよ いが経済的ではない。

Orsefort ${ }^{163)} ら は p p^{\prime}$ diaminodiphenylmethane; $\mathrm{NN}^{\prime}$ dinonyl $p$-phenylenediamine; $\mathrm{NN}^{\prime}$ dioctyl $p$ phenylenediamine; $N N^{\prime}$ di $4(2,6$ dimethyl heptyl). p-phenylenediamine; $\mathrm{NN}^{\prime}$ di ( 1 'methyl octyl)-pphenylene diamine ならびにその関連物質約 20種につ いて実驗してこの4種が有効であることを認めた。

4010るすぐれたるのである186)。またハラミンのNN” の犆換基がどんなすのが有奻かという研觉がなされてい

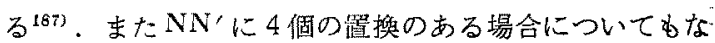
されている、またパラミンのフェニレンの代りに他の基 を入れたものの研究もなされて，その結果はフェニレン が一番よかった。使用には antiozonant 3-5 部ワック ス1ー3部を用いるのがよいといわれている188)。

antiozonant の作用機粠としては，酸化防止成の上了 な chain stopper のようなものでなくて，オン゙ンと直 接反応してオン゙ンをつぶしてしまうすのであると考え られる(89)。このさい antiozonantは，たと充ば NN dialkyl-p-phenylene diamine では 1 モル当り 4 モル のオン゚ンが消責され芳香族核の破墁がおこる

この方面でも非汇染性の毒性のすくないものか㴗望さ れている. Dialkoxy 4 alkyl phenol'191), tetra alkyl p-phenylene diamine $\mathrm{NH}_{2}-\mathrm{R}_{\mathbf{R}^{\prime \prime \prime}}$ 污染性の酎オゾン郕である。 
文

1) a) C. Walling : Free Radical in Solution, G. Wiley \& Son Inc. (1957).

b) K.G.Bailey : The Retardation of Chemical Reactions (1937).

c) C. Ellis : The Chemistry of Petroleum Derivatives, Chemical Catalog Co. (1934)889.

d) C. E. Frank : Chem. Rev., 46, 155-69 (1956).

e) General disc. Fraday Soc., 42, 99-308(1946).

f) R. G. Lesson : Anal. Chem., 20, No.6, 547 (1948).

g) Waters : Mechanism of Oxydation in Annual Rept. on Progress Chem. (Chem. Soc. London) 42, 130-59 (1946).

h) G.H. Von Fuchs \& H. Diamond : Ind. Eng. Chem., 34, 927-39 (1942).

i) G. H. Denison:Ind, Eng. Chem, 36, 477-82 (1944).

j) G. Le. Bras : Compt rend, 217, 297 (1943) R.C.T. 18, 22 (1945).

k) T. G. Grave : India Rubber J.,107,657(1944)

1) A.S. Carpentee : Ind, Eng, Chem., 39, 187 (1947).

m) 大北忠雄, 住友電工践報: 37, 51 (1950).

n）小島寬男：ゴ么協 25，315. (1952)

o) H. Hock, H. Kropf : Ang. Chem. 69, 313340. (1957)

2) a) J.M. Buist : Rubb. Chem. Technol, 28, 230 (1955).

b) 大北忠男 : ゴム協 24,67(1951); 電気学会有機 材料㸓化專門委員会凟料 OD-7.

c) B.S. Biggs : Bell System Tech.J.,1078(1951).

d) J.T.Blake : ASTM Special Tech. Publications, 8948 (1949).

e) 吉川充雄 : ゴム協, 28, 755 (1955).

3) Brooks, Humphry : J. Am. Chem. Soc., 40, 822-56. (1918)

4) Egloff, Morell, Dryer, Lomry : Ind. Eng. Chem. 28, 465-70. (1936)

5) I. C. : $897,907$.

6) Titoff : Z. Phys. Chem., 45, 641 (1903). Warburg, Ber. 58, 1001 (1925).

7) H.S, Taylor: J. Phys. Chem., 27, 322(1923).

8) F. Perrin : Compt rend, 84,1121(1929).

9) C. Mourou, C. Dufraise : J.Soc.Chem. Ind., (1925).

10) G. J.Van Amerogen : Ind. Eng.Chem., 47, 2565(1955).

11) J.R. Shelton, W. L. Cox : Ind. Eng. Chem., 42, 456(1951), 45, 392(1953).

12) J. R. Shelton, H. Winn : Ind. Eng. Chem., 41, 728 (1950).

13) G. T.Kohman : J.Phys. Chem.,33, 226(1929).
献

M. C. Reed : Ind. Eng. Chem, 21, 316(1929).

14) James: Ind.Eng. Chem., 17, 871(1925).

15) S. Boxter, W. M, Morgen \& D.S.P. Roebuch: Ind. Eng. Chem., 446(1451).

16) J. R. Shelton, H. Winn : Ind. Eng. Chem., 38, $71(1946)$.

17) Engler, Bach, Ber., 33,1097 (1900) Compt rend 951 (1897).

18) Glover: J.Am.Chem. Soc., 44, 1107(1922).

19) A. Rieche, R. Meister : Ang. Chem., 49, 101 (1936).

20) R. Criege, H. Pilz \& H. Elygare: Ber., 72, 1562(1939).

21) H. Hock, A. Neuwirch : Ber., 72, 1799(1939).

22) H.S. Taylor, J.O. Smith: J.Chem. Phys., 8, 593 (1940).

A. D. Walsh : T. Faraday Soc,42, 269(1946).

P. George, A. D. Wulsh : ibid, 42, 272(1946).

23) E. H. Farmer, et.al. : J.Chem.Soc. (1942) 121, 139, India Rubb. J., 112, 84, 119, (1947) Trans. Faraday Soc., 228(1946), 38, 340 (1942), W. A. Water : Ann.Rept, 42, 130 (1948).

24) H. Hock: Ber., 71, 1430(1938). Robertson: J.Chem. Soc.(1940)1574, Bateman : Trans. Faraday Soc., 48, 1149 (1952).

Bolland : ibid, 42, 236(1946).

25) G. A. Gefrey : Proc. Roy. Soc., 188A, 222 (1947).

26) Laurence, Shelton:Ind. Eng. Chem., 42, 136(1950).

27) J.Cortyl, Lacau : Rubb. Chem. Technol. 746 (1955).

28) E. H. Farmer: Trans. Faraday Soc, 41, 122 (1945), 42, 228(1946).

29) Atherton, Hilditch: J. Chem. Soc. 105 (1944).

30) Bolland, Gee : Trans. Faraday Soc, 42, 244 (1946).

31) Cullis, Hinshelwood Trans. Faraday Soc. disc. (1947)117.

32) Walsh : Trans. Faraday Soc.disc. (1946)269.

33) Walsh: Trans. Faraday Soc., 43, 297(1947).

34) Waters: The Chemistry of Free Radical 2nd Ed. 226-58, Oxford (1948).

35) J. E. Field : Rubb. Chem. Technol. (1955)771.

36) E. M. Bevilaqua: J.Am. Chem. Soc. 77. 5396 (1955)

37) A. V. Tobolsky, D. J. Metz \& R. B. Mesrobian: J.Am.Chem.Soc, 72, 1942(1950).

38) J. L. Balland, H. Hughes : J. Chem. Soc, 492(1949). 
39) B. S. Sekher : Rubb. Chem. Technol., 31,425 (1958).

40) 永井宏，工化，531（昭17） 509-511.

41) J.R.Schelton, W. L. Cox : Ind. Eng. Chem. (1953)392; Ind. Eng. Chem. (1954)816.

42) W. Neal : Ind. Eng. Chem, 22, 894(1930).

43) Peachy, Leosn : J.Soc.Chem.Ind. 37, 55T. (1918)

44) J.R. Schelton, F. J. Wheely, W.L. Cox : Rubb. Chem. Tebhnol. (1950)120; Ind. Eng.

Chem. 45, 2080. (1953)

45) W. Neal : Ind.Eng. Chem, 21 1288. (1929)

46) R. C. Stafford : Rubb. Age 700. (1954)

47）小出武城，久保田威夫，下田哲雄，昭和30年コ 么協講演会

48) P. Thircon: Rubb. Age (1956)531.

49) Schelton, Winn : Ind. Eng. Chem. (1954)596 $D \operatorname{ref}(6)$.

50) Morgan, Newton: Proc. Rubb.Tech. Conf. London (1938) 537.

51) Le Bras: Rubb. Chem. Technol.,23, 374(1950).

52) L. Bateman, G. Gee : Trans. Faraday Soc., 47, 274(1951).

53) D. V. Evans: J.Chem. Soc. (1953)345.

54) A. S. Kuzminskii, L. L. Shanin, N. N. Lezhnez: Doklady Akad. Nauk. S.S.S.R. 467 (1951), Rubb.Chem. Technol. (1952) No.1.

55) Lacau : Compt. rend, 224, 917(1947).

56) a) E. H. Farmer : Trans. F araday Soc., 38, 340 (1942);42, 228(1946),

Faraday Soc. General disc. (1946) 99-398 (1947).

b) L. Batteman : Quart. Rev. (London) 8, 147 (1954).

c) J. C. Bolland : Proc.Roy. Soc. (A) 218(1946).

57) H. Hock, G. Knavel : Chem.Ber., 84, 1(1951).

58) R. Criege, G. Müller : Chem. Ber., 89, 238 (1956).

59) a ) Trans. Faraday Soc., 49, 1026(1953).

b) Faraday Soc. General disc., 10,250(1951).

c) L. Bateman, G. Gee : Proc. Roy. Soc. (London) 195A, 391 (1948).

60) L. Bateman, G. Gee : Proc. Roy. Soc., A195, 376(1949).

61) G. H. Bamford, M. J. S. Dewar : ibid, A192, 309 (1948).

62) 藤井，高分子，2，441(1953).

63) C. Bateman : Trans. Faraday Soc., 47, 155, 274(1951).

64) L. Bateman, G. Gee : Disc. Faraday Soc, 10, 250 (1951).

65) L. Bateman, G, Gee : Trans. Faraday Soc, 47, 155(1951).

66) L. Bateman : Quart.Rev, 8, 147(1954).
67) L. Bateman, Miss. H. Hughes : J. Chem. Soc, 4594(1951).

68) Bolland : Trans. Faraday Soc, 46, 358(1950).

69) H.W. Melville, S. Richards : J.Chem. Soc. (1954) 944.

70) C. H. Bamford, M. J. S. Denison : Prac. Roy. Soc, A198, 252.

71) V. Kellö, A. Tkac : Chem. Zvesti, 7, 129-40 (1953). C. A. 8574(1954). Rubb. Chem. Technol. (1965). 968.

72) 加藤, 增尾: 化学の領域 (1958) 12, 43.

73) Walsh : Trans. Faraday Soc.,43, 297(1947).

74) George, Robertson : J. Inst. Petr., 32, 400 (1946).

75) H. Hock, F. Dephe: Chem. Ber. 84, 356 (1951).

76) H. Hock, F. Dephe, G. Knaul : Chem.Ber., 83, 238(1950).

77) R. Criegce : Bex, 71, 22(1944), 84, 215(1951).

78) G. A. Russell : J.Am. Chem. Soc., 78 1047, (1956).

79) Szwarc: Chem. Rev, 47, 75(1950).

80) Bateman, Koch: C. A. 38, 277 (1949).

81) a) A. Robertson, W. A. Water: Trans. Faraday Soc., 42, 201(1946).

b) A. E. Woodward, R. B. Mesrobian : J. Am. Chem. Soc., 75, 6189(1953).

c) P. George, A. Robertson : Trans. Faraday Soc., 42, 217(1946).

d) C. E. H. Bawn, T.B. Williamsen : Trans. Faraday Sac., 47, 735(1951).

82) G. C. Bolland, D. T. Mave : Trans. Faraday Soc., 201(1947).

83) N. A. Milas, D. M. Surgenor : J.Am. Chem. Soc., 6B, 205(1946).

84) E. R. Bell, J.H. Raley, F.E. Rust, F.H. Senbold \& W. E. Vaughan : Disc. Faraday Soc, 10, 242(1953).

85) V.Staunett, R. B. Mesrobian : J.Am. Chem. Soc., 72, 4125(1950).

86) C. Walling, Y.W. Chang: J.Am.Chem. Soc, 76, 4878 (1954).

87) George, Walsh : Trans. Faraday Soc., 42, 94(1946).

88) A. Forkas, E. Darsuglia : $J . A m$, Chem. Soc, 77, 333(1950).

89) K.I. Evans, et. al. : C.R. Akad.Sci.S.S.S. $R ., 25,297(1947)$

90) H.S. Master, C. F. Wurster : J. Am. Chem. Soc., 71, 5451(1955).

91) G.W.Wheland : Advanced Organic Chemistry; 2nd ed. John Wiley \& Son New York (1947) 694.

92) W. A. Waters: The Chemistry of Free Ra- 
dical : Oxford Press (1948).

93) N. A. Kahn: Can. J.Chem., 32, 1149(1954). 94) a) A. Robertson, W. A. Waters : J. Chcm. Soc. (1948) 1578.

b) A. Farkas, E. Passaglia: J.Am. Chem. Soc., 72, 3333. (1950)

c) O.Starnet, R. B. Mesrobian : J.Am.Chem. Soc., 72, 4125. (1950)

d) M. S. Kharash, A. Fons\&W. Nudenberg : $J$. Org. Chem., 16, 113(1951).

95) L. Bateman, H. Hughes, A. E. Morris : Disc. Faraday Soc., 14, 190(1933).

W. Kern, H. Wilbersinn : Ma?romol.Chem.

15, 1(1955).

Angew.. Chem., 67, 573(1955).

96) C. E. H. Bawn, J. B. Williamson: Disc. Faraday $S o c ., 14,181(1953)$.

97) a) F. A. Boney, I. M. Kolf off : J. Am. Chem. Soc, 69, 2143(1947).

b) C. E. Barnes, R. M. Elafson, G. D. Jones : $J$. Am. Chem. Soc, 72, 210(1950).

c) A. A. Miller, F. R. Mayo: J.Am.Chem.Soc., 78, 1017(1956).

.98) N.A.Milas : Proc. Natl. Acad. Sci, 14, 844 (1928).

S. Medredev, P. Zeitlin : Acta Physico Chim. $S S S R$., 20. 3(1945).

H. Trennex : Chem.Ztg., 74, 692 (1950).

99) C. E. Boozer, B.E. Ponder, J.C. Trisler \& C. E. Wightman : J.Am. Chem. Soc., 78, 1506 (1956).

100) Lewis, Boozer : J.Am. Chem. Soc. (1954) 791.

101) Hommond, Boozer: J. Am. Chem. Soc., (1955) 3243.

102) J.H. Raley, C.M. Porter, F. F. Rust \& W. E, Vaughan: J.Am.Chem.Soc, 73, 15(1951).

103) F. H.Senbald, F. F. Rust \& W. E. Vaughan: J.Am.Chem.Soc., 73 18, (1951).

104) C. F. Frank: Chem. Rev. (1950) 155.

105) Hock, Ganishe: Ber., 71, 1430(1938).

106) Emarson, et. al. : J.Am. Chem. Soc, 70, 3764(1948). ref (4), (34).

107) W. Frank: Liebigs Ann. Chem., 498, 129 (1932).

108) J.P.Fortnin, T. H. Dissert : Delft, 1921.

109) A.C.Cope, G. Hulzman : J. Am. Chem. Soc., 72, 3062(1950).

110) George, Robertson : J. Inst. Petroleum, 32, $400(1946)$.

111) F.F. Francis: J.Chem Soc., 121, 502(1922).

112) Hinshelwood, Cullis : Disc. Faraday Soc. 117 (1947).

113) H. Schlenk, et al:J.A.C.S. (1955) 3587; Fortshr. Chem. Forsch., 2, 92 (1951).
114) K. I. Ivanov, E. D. Vilyanskaya : Doklady, Akad. Nauk S.S.S.R., 102, 551 (1955);C.A., 50, 2259a.

115）松本保夫：東北大非水研，日化第 7 年会, 13075.

116) R.M. Noyes: J.A.C.S. (1955) 2042.

117) G. W. Kennerly, W. C. Patterson : Ind. Eng. Chem., (1956) 1917.

118) R. G. Losen, H. A. Armfield : Ind. Eng. Chem. (1943) 581.

119) J. C. Bolland, P. Ten Have : Trans Faraday Soc., 43, 201 (1947).

120) I. C. G. Angert, A.S. Kuzminski:J. Polymer Sci., 32, 1 (1958).

121) J.O.Cals, J. E. Field : Ind. Eng. Chem., 29, 174 (1947).

122) U. S. $2407051,2680106,2617748,2157068$, 2126179, 2317481.

Meyer, Gearhart : Ind.Eng.Chem., 37,212 (1945); 43, 1585 (1951).

123) A. W. Bartel, J.W.Temple:Ind.Eng.Chem., 44, 857 (1952).

124) G. H. Dennison, Jr. : Ind. Eng. Chem., 36, 477 (1944); 37, 102 (1945); 41, 944 (1949).

125) L. Bateman, J.I. Cunnen: J.C.S. (1955) 1596.

126) G. M. Murply, Jr. H. Ranner, N. L. Smith: lnd. Eng. Chem., 42, 2499 (1950).

127) P. D. Barilett, K. Nozaki : J. A. C. S., 68, 1686 (1946); G. G. Swain, W. H. Stockmayer, J. T. Glarke : J.A.C.S.,72, 5426 (1950); J. R. Thomas: J.A.C.S., 77, 246 (1955).

128) H. Hock, S. Lang:Ber, 77B, 257 (1944).

129) L. Bateman, F.W. Shipley : J.C.S. (1955) 1996.

130) Le. Bras : Rev. Gen. Caoutichuc, 25, 3 (1949).

131) J. Le. Fall : R. C. T, 27, 157. (1954)

132) Le. Bra, et al:J.Polymer Sci, 27, 529 (1958); R. C. T. (1958) 849 .

133) 小出寘次：化学の领域11，24. (1957)

134) Eeley: Trans. Electrochem. Soc. 69, 195. (1936)

Doede : C. M. Proc. Tech. Conference(1938) 730.

135) Bollond, Ten Have : Disc. Faraday Soc., 2, 252 (1948).

136) C. D. Loury, G. Egloff, J.C. Morrell, C. G. Dryer:Ind. Eng. Chem., 25, 804 (1933);24, 1375 (1932).

137) A. S. Kuzminskii, L. G. Angert : Doklady Akad. Nauk S. S. S. R. 96, 1187; (1954) R. C. T. 29, 131. (1956)

138）村田二郎, 大内重男, 埜田幸男：ゴム協(昭24) 3 月.

139) W. G. Lloyd, W. T. Lippincott : Am. Chem. 
Soc. Annual Meeing (1957) 87-0, 148.

140) A.F. Bickel, E. C. Koozman: J.C.S. (1956) 2215.

141) Rosenmald, Houston, Chenicek : Ind.Eng. Chem, 42, 162 (1950).

142) Wasson, Smith : Ind. Eng. Chem, 45, 197 (1953).

143）松田，山田：工化，60，566 (1957).

144) Stillsen, Sawyer, Hart: J.A.C.S, 67, 303 (1945).

Coggeshall:J. A. C. S, 69, 1620 (1947).

McKinlly : J. A. C. S., 69, 1624 (1947).

145) Boozer, Hammond, et al.
a) J.A.C.S., 76, 3861 (1954).
b) J.A.C.S., 77, 3233 (1955).
c) J. A. C. S., 77, 3238 (1955).

146) a) Deary : C. R., 36, 145 (1945).

b) Hunter, Barhort, Proust : Ind. Eng. Chem., 46, 1524 (1954).

147) W. R. Hatchard, et al:Am.Chem. Soc. Annual Meeting, 1958, 27, Organic Div.

148) G. E. K. Branch, M. Caluin : Theory of Org. Chemistry, 315-7 (1941) Practice Hall.

149) C. J.Rederson : Ind. Eng. Chem, 48. 1881 (1956)

150) J.R. Shelton, E. T. McDonell : J. Polym. Sci., 32, 75 (1958).

151) C. Walling, R. B. Hodydon : J.A.C.S., 77, 231, (1958).

152) T.W. Compbell, G. M. Coppinger : J.A.C. S., 74, 1469 (1952).

153) J.J. Batten, M.F.R. Mulcahy : J. C. S., (1956) 2948.

J. J. Batten : J. C. S., (1956)2958.

154) A. F. Bickell, E. C. Koogman: J.C.S. (1953) 3211.

155) Coak: J. Org. Chem., 18, 261 (1953).

156) P. Schneoder: Rub. Age (1954) 537.

157) Cosgrove, Waters:J. C. S. (1951) 1726. Woters, John: J. C.S. (1951) 812.

158) J.R.Runn, W.A. Waters, C.W. Gones : J. C. S. (1952) 2427.

Moore, Waters : J. C. S. (1952) 2432.

159) R.S.Mulliken: J.A.C.S., 74, 811 (1952).

160) A.S. Kuzminskii : R. C. T. 29, 145 (1956),

161) a) 熊谷：日石技報，640.

b) 平川管彦：有機合成，13,509 (1955).

c) 豊口満：有機合成，13,512 (1955)。

d) J.D.Bertbson : Ind.Eng.Chem., 41, 448 (1949).

162) W. A. Zisman:Ynd. End.Chem.45, 147(1949).

163) U. O.P. Booklet : No. 224.
164）久保田威夫, 栗林愿: 有機合成协, 13, 533(1955)。

165) R. A. Youmans, G. C. Massen Ind. Eng. Chem., 1487 (1955).

166) C.R. Pollack:India Rub World, 130, 53(1954).

167) E. N. Novikowa et al: Izvet. Akad. Nauk. Belsruss S.S.R. 5, 125 (1953); C. A. 50, $142 E 6$ (1956).

168) C. J. Kitchen, H. E. Alhert, G. E.P. Smith: Ind. Eng. Chem., 675 (1950).

169) Morawetz: Ind.Eng.Chem., 41, 1442 (1949).

170) Hunter, Bornhart, Proust:Ind.Eng. Chem.s, (1954) 1524.

171) U.S. 2419354:(1947).

172) Vaft, Duke, Prem, Harrison : Rub. Age 70, No. 2 (1956).

173) A. HaekI : R. C. T.,27, 147 (1954). Lyon, Burgass, Swectzer : Ind. Eng. Chom. 46, 596 (1954).

174) Shelton, Cox, Wickhim : Ind. Eng. Chem., 47, 2559. (1955)

175) Le. Bras:R.C.T.,20, 949, 962(1947); Le. Foll: R.C.T., 47, 2559(1954); J. R. Shelton, W. Cox: Ind. Eng. Chem. 43, 456 (1951).

176) K.A. Burgess, C.W. Sweitzer:Ind.Eng Chem., 47, 1820 (1955).

177) F. Von Spalak: Symposium on Ageing of Rubb. Svenges Gummi Tekniska Forenring (1955) p. 33 .

178) U.S. 2742349.

179) U.S. 2942350.

180) B.S. Briggs : Rubb. Chem. Tech., 31. 1015. (1958)

181) W.F. Tuley : Ind.Eng. Chem., 31, 714(1939).

182) D. C. Borton: U.S. 2324056.

183) K. E. Creed, et al : Anal. Chem., 2B, 241 (1953).

184). J. E. Gaughan : Rub. World, 132, 138 (1956).

185) R.F. Shaw, Z. T. Ossefert, W. Touhey:Rub. World 130, 636. (1954)

186) Smith, Tuley : Rub. Meeting Chicago(1958).

187) (180) Ref (95) Bruce, F.C.

188) G. N. Vacca, St. Louis : Symposium ASTM Feb. (1958). C. V. Lundberg, et al : Rub. World, 135, 649. (1953).

D. C. Edward, et al : Rub. Age, 79, 987(1956).

189) A.D.Delmam, et al : Anal.Chem., 26, 1589. (1954).

F. H. Kendall : J. Polymer Sci.,19, 503(1956).

190) (180) Ref (16).

191) Coocks : Chemik. 特公昭33-2640.

192）特公昭33-2486. 